تأثير استخدام بعض أساليب الخاع على فعالية الأداءات الهجومية المركبة لناشئي الكوميتيه في رياضة الكارات

تأثير استخدام بعض أساليب الخداع على فعالية الأداءات الهجومية المركبة

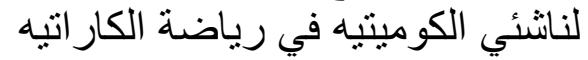

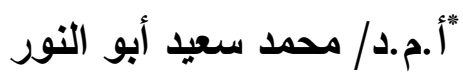

المقدمة ومشكلة البحث:

تعتبر مسابقة الكوميتيه من المسابقات الهامة في رياضة الكاراتيه التي تتميز بتتوع

اساليب أداء المهارات الهجومية والدفاعية خلال مبارياتها، ما بين أساليب مباشره وغير مباشرة والتي يتوقف استخدامها على طبيعة المواقف التتافية المختلفة التي يتعرض اليها اللاعب أثناء عملية التتافس مابين مواقف هجومية خاطفة ومواقف هجومية مضادة ومواقف دفاعية، يحتاج كل موقف منها الى تصرفا خططياً مختلفاً عن الأخر ووفقاً لاختلاف محددات الموقف التتافسي بين مباراة وأخرى.

ويشير محمد سعيد أبوالنور (q . . r م) الى أن الهجوم في الكوميتيه بأنواعه المختلفة هو العامل الرئيسي لحصول اللاعب على أكبر عدد من النقاط سواء كان هذا الهجوم هجوماً بسيطاً أو هجوماً مركباً أو هجوماً مباشراً أو غير مباشراً، كما أن الأسلوب الحديث في رياضة الكاراتيه والخاص بلاعبي الكوميتيه بعتمد على سرعة ودقة تتفيذ المهارات الهجومية أثناء المباريات ووصول هذه المهارات إلى أهدافها المختلفة سواءً باستخدام الذراعين أو الرجلين وأهمية توظيف إمكانات اللاعب المختلفة أثتاء المباريات ووفقاً لقدراته واستعداداته حتى يمكن تتفيذ الواجبات الهجومية والدفاعية المختلفة بفعالية أثناء المباريات مع الإقتصاد في بذل الجهد أثثاء الأدوار

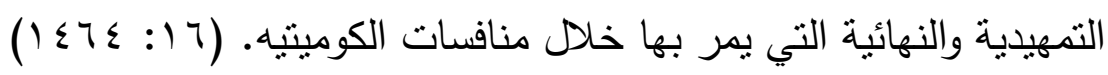

ويذكر عماد عبدالفتاح السرسي (1 . . P م) أن التدريب على الكوميتيه يتطلب الإعداد المهارى الجيد عن طريق استخدام الحركات الخداعية فى التدريب من خلال سرعة التحرك فى جميع الزوايا حول المنافس مع مراقبة حركاته الخداعية ومحاولة كثف ثخرة فى جسمة مع سرعة الاستجابة الحركية الصحيحة بمهارة مناسبة مع تغيير وضع جسمة بسرعة وقوة الهجوم المباشر

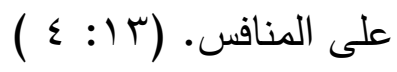

ويشير شريف محمد العوضي، عمر محمد لبيب (ع . . rم) إلى أن لاعب الكومينيه ذو المستوى المهاري المتقدم بجانب إجادته المهارات ونمو قدراته الحركية يحتاج إلى الإلمام بحركات الخداع والتي تعتبر من أهم العوامل المساعدة لتحقيق النصر، ومحاولة خداع المنافس إهى

"أستاذ مساعد بقسم نظريات وتطيقات المنازلات والرياضات الفردية بكلية التربية الرياضية للبنين جامعة الزقازيق 
عن طريق استعمال بعض حركات الخداع بغرض إبعاد وتشتيت تفكير المنافس وفتح ثغرة لبدء

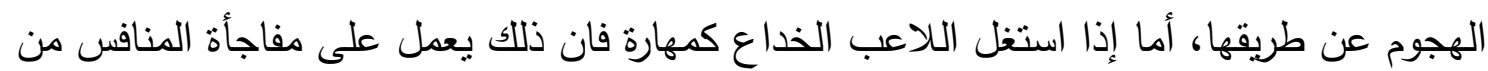

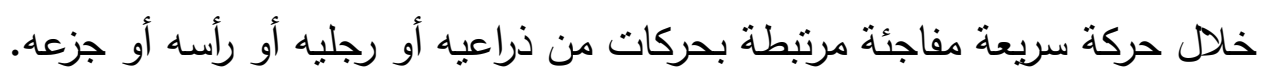

(YYT: 1.)

كما يوضح عبدالفتاح فتحي خضر (7 9 ام) أن الخداع هو فن استخدام الجسم بالتظاهر

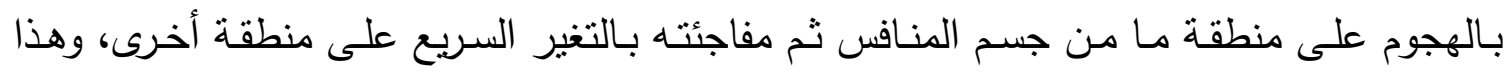

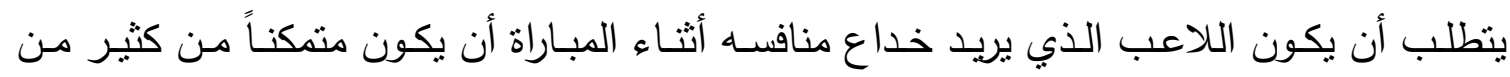
المهارات الحركية الخداعية حتى يمكنه من استخدام الحركة الصحيحة والمناسبة للمواقف الهجومية

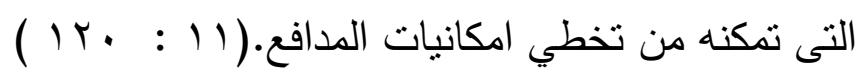

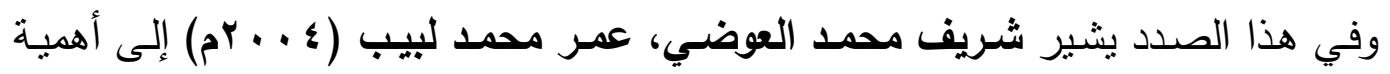

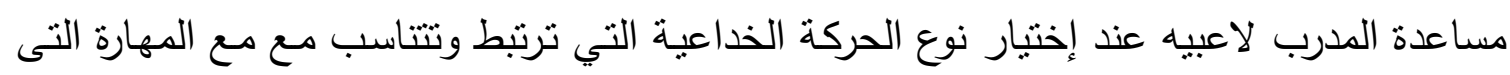

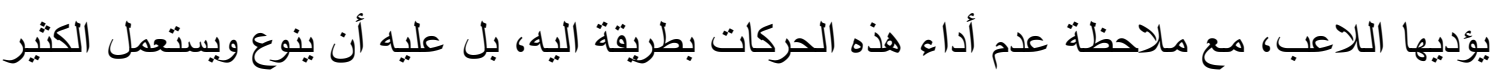

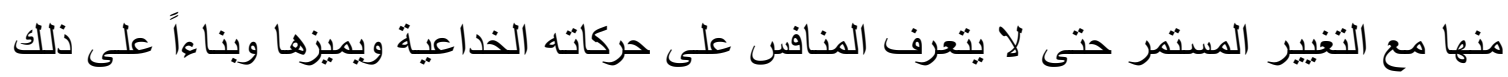

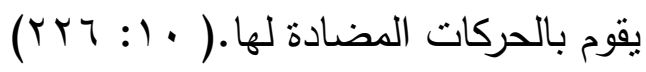

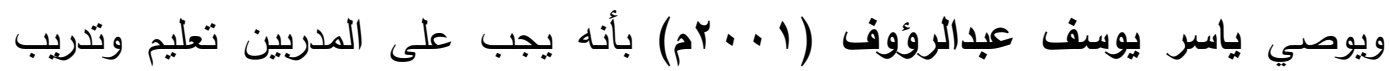

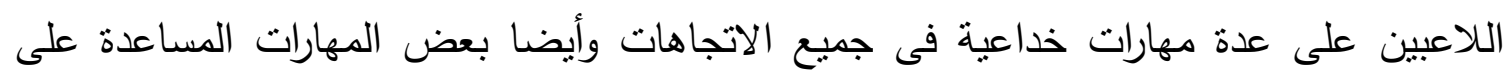

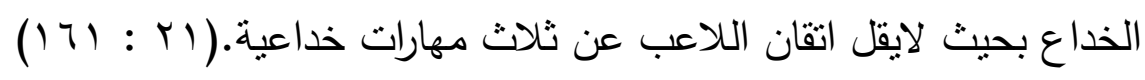

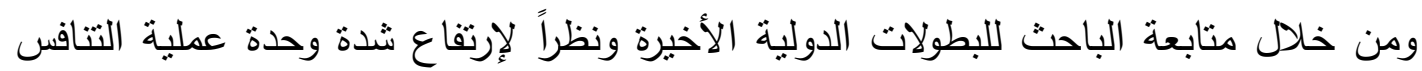

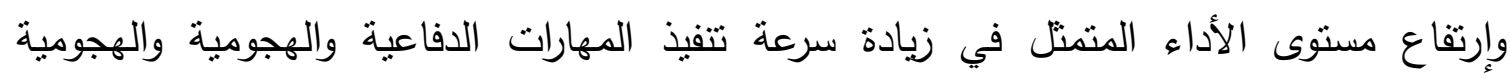
المضادة، فقد وجد الباحث أهمية استخلال كل إمكانات وقدرات اللاعب البدنية والمهارية والخططية في اختراق مجال المنافس للحصول على النقاط، حيث لم يعد الهجوم المبانر كافياً لتحقيق ميزه

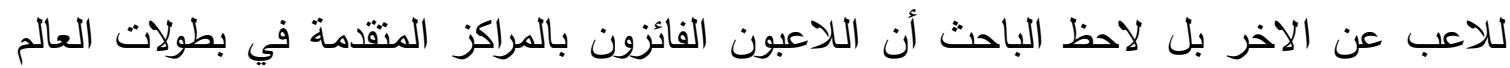

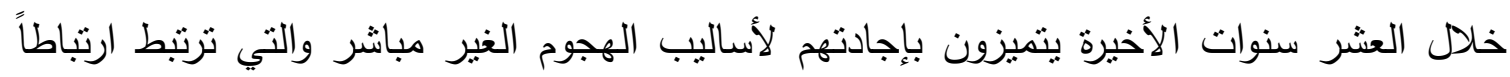

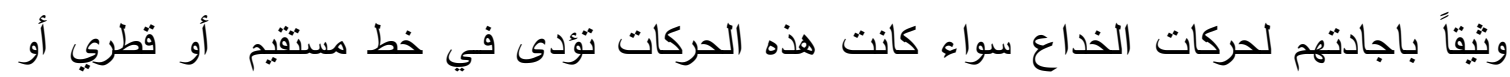

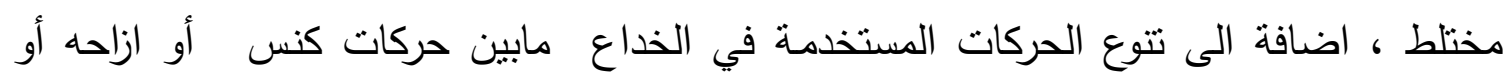
حركات رمي أو مهارات تمهيدية تشتت انتباه المنافس. 
تأثير استخام بعض أساليب الذاع على فعالية الأداعات الهجومية المركبة لناشئي الكوميتيه في رياضة الكارات

ومن خلال العرض السابق ومن خلال ملاحظة الباحث ومتابعته لبطولات الإتحاد المصري

للكاراتية بشكل عام ومنطقة الثرقية للكاراتيه على وجه الخصوص في مسابقة الكوميتيه للناشئين في المرحلة السنية تحت 17 سنه فقد لاحظ الباحث عدم نجاح العديد من الأداءات الهجوميـة في

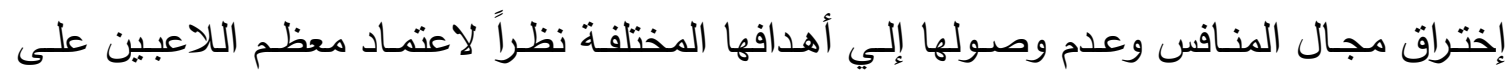
الهجوم المباشر وعدم استخدام الهجوم الغير مباشر والمتمثل في التمهيد بأداءات خداعية عند القيام بعملية الهجوم على المنافس.

حيث أدى ذلك إلي التأثير بشكل مباشـر علي فعالبـة النشـاط الخططي أثتاء المباربـات والمتمثل في إنهاء العديد من المباريات بإنتهاء زمن المباراة وليس بتحقيق فارق الستة نقاط بين اللاعب ومنافسـه كما هو وارد بقانون الاتحاد الدولي لرياضـة الكاراتيه، حيث أن إستمرار المنافسـة

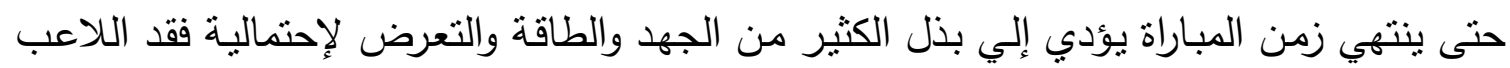
العديد من النقاط، في حين أن اللاعب القادر علي تتفيذ ثلاثة أو أربعة أداءات هجوميـة مركبـة

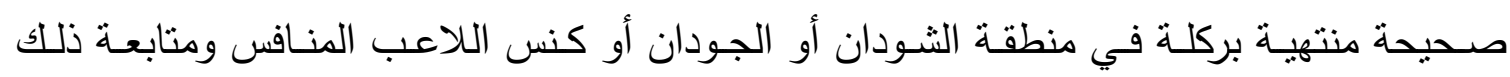
بالتسديد يستطيع اللاعب الفوز بالمباراة في أقل وقت وذلك لإستغلال باقي زمن المباراة في الراحة

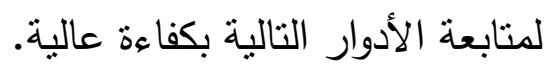

وإضافة لما ذكر ومن خلال المسح المرجعي للعديد من الدراسات السابقة وجد أنة لم توجد دراسة - في حدود علم الباحث- تتاولت منل هذه المشكلة بالبحث، مما دعا الباحث إلى تتاول مثنل هذه المشكلة بالبحث والدراسـة وذلك بهدف التعرف على: "تأثير استخدام بعض أسـاليب الخداع على فعالية الأداءات الهجومية المركبة لناشئي الكوميتيه في رياضة الكاراتيه " هدف البحث:

يهذف البحث إلى التعرف على: تأثير استخدام بعض أساليب الخداع على فعالية الأداءات الهجومية المركبة لناشئي الكوميتيه في رياضية الكاراتيه": فروض البحث:

1- توجد فروق دالة إحصائياً بين القياسين القبلي والبعدي في فعالية بعض أساليب الخداع والأداءات الهجومية المركبة لدى المجموعة التجريبية ولصالح القياس البعدي. ץ- توجد فروق دالة إحصائياً بين القياسين القبلي والبعدي في فعالية بعض أساليب الخداع والأداءات الهجومية المركبة لدى المجموعة الضابطة ولصالح القياس البعدي. ب- توجد فروق دالة إحصائياً بين القياسين البعديين للمجموعتين التجريبية والضابطة في فعالية بعض أساليب الخداع والأداءات الهجومية المركبة ولصالح المجموعة التجريبية. 
تأثير استخذام بعض أساليب الذذاع على فعالية الأداعات الهجومية المركبة لناثئي الكوميتيه في رياضة الكارات

ع - توجد فروق في نسب التحسن بين المجموعتين والتجريبية والضابطة في فعالية بعض أساليب الخداع والأداءات الهجومية المركبة ولصالح المجموعة التجربيية. مصطات البحث: أساليب الخداع** (

هى عبارة عن "مجموعة من الأساليب التي يستخدمها اللاعب ليمهد بها لفتح ثخرة أو

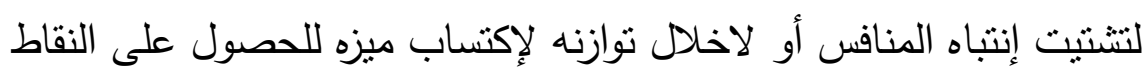

\section{الأداعات الهجومية المركبة :}

هى عبارة عن "مجموعة من الأداءات المهارية المعدة والمرتبة وفقاً لأهداف حركية وخططية معينة تتتاسب مع المواقف التي يتعرض إلبها اللاعب أثناء عملية التتافس وتؤدى ولئ باستخدام اليدين أو القدمين أو بالمزج بينهما".

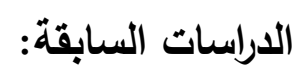

1 - أجري منعم فاروق جمعة:(9 9 (1)(9 19) دراسة هدفها التعرف على أثز تطوير بعض أنواع الخداع على مستوى الانجاز في الماكمه ، وقد استخدم الباحث المنهج التجريبي المجموعتين التجربيية والضابطة على عينة قوامها ـ ب لاعب من لاعبي المنتخب العسكري ، وكانت اهم النتائج هى ارتفاع مستوى الاداء ودرجة الفعالية بالنسبة للخداع المستخدم والتاثير المباشر للخداع المستخدم على جميع متغيرات الاعداد المهاري للكمات الاساسية من حيث عدد اللكمات ومستوى الاداء ودرجه الفاعلية.

r- قام "محمد سعيد أبو النور:(r . rم)(0) بدراسة هدفها التعرف على فاعلية تطوير بعض المهارات الهجومية المركبة على نتائج المباريات للاعبى الكاراتيه، وقد استخدم الباحث المنهج التجريبي بتصميم مجموعتين احداهما تجريبية الأخرى ضابطة على عينة قوامها . ؛ لاعب، وكانت اهم النتائج هى زيادة فعالية السلوك الهجومي للمهارات الهجومية المركبة ثنائية وثلاثية ورباعية التركيب المهاري قيد الدراسة، وظهور فروق معنوية في نتائج المباريات لصالح المجموعة التجريبية مقارنة بالمجموعة الضابطة. r- أجرى "ابراهيم على الابيارى"(r . . rم)(1) دراسة هدفها تطوير بعض الخطط الهجومية وتأثيرة على نتائج المباريات لدى ناشنئى رياضة الكاراتيه، وقد استخدم الباحث المنهج التجريبي بتصميم مجموعتين احداهما تجريبية الأخرى ضابطة على عينة قوامها با لاعب تتراوح 
تأثير استخدام بعض أساليب الخذاع على فعالية الأداءات الهجومية المركبة لناشئي الكوميتيه في رياضة الكارات

اعمارهم من ع ا-1 ا سنة، زيادة الحصيلة المهارية للاعبين وزيادة الحصيلة الخططيه للاعبين وزيادة المساحة الخططية وحسن التفكير •

צ - أجرى علاء محمد حلويش و عمرو محمد حلويش (r . . r م) ( ) ): بدراسة هدفها التعرف على تأثثر برنامج تدريبي بإستخدام التدريبات النوعية لتحركات الرجلين أثناء أداء الموجات الهجومية ( كتدريب أولي) للاعبي الكاراتيه وتأثثرة علي تحقيق الإنجاز المبارائي، وقد استخدم الباحثان المنهج التجريبي بتصميم المجموعتين قوامها ـ ا ل لاعبين من لاعبي نادي الأهلي بدبي

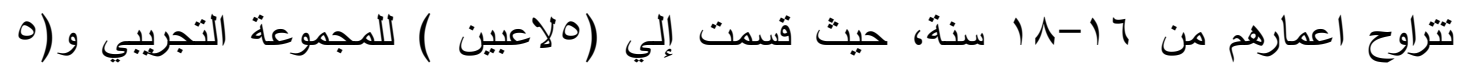
لاعبين) للمجموعة الضابطة وكانت أهم النتائج ان البرنامج التذريبي المقترح كان له تأثير ايجابي على تحقيق الانجاز المبارائي لدى عينه البحث.

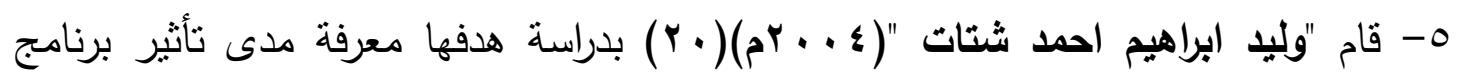
تدريبي باستخدام بعض حركات الخداع على مستوى الانجاز لدى لاعبي رياضة الجودو ، وقد استخدم الباحث المنهج التجريبي بتصميم مجموعة تجريبية واحدة قوامها ^ لاعبين من منتخب الغربية للجودو تحت ^/ سنه، وكانت أهم النتائج هى أن البرنامج التدريبي المقترح أدى الى الى رفع مستوى الأداء الفني للحركات الخداعية والمهارات المصاحبة بشكل ملحوظ.

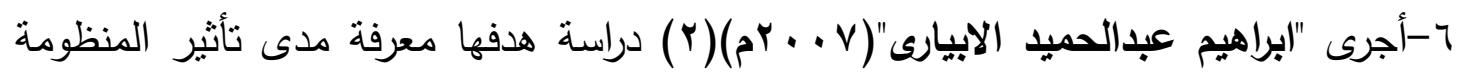
الخططية لاختراق مجال المنافس على فاعلية الأداء لدى لاعبى رياضة الكاراتيه، وقد استخدم الباحث المنهج التجريبي بتصميم مجموعتين احداهما تجريبية الأخرى ضابطة على عينه قوامها ع Y لاعب، وكانت اهم النتائج هى زيادة فاعلية ادارة زمن المباراة واختراق مجال المنافس، وزيادة المساحة الخططية لحسن تفكير وتصرف اللاعبين مع استغلال مساحات الملعب وخاصة المساحات الركنية

- Vام أحمد محمد الشحات (11 + Y م) (r) دراسة استهدفت التعرف على: تأثير برنامج تذريبي مفترح لتحسين حركات الخداع وتأثنيره على معدل فاعلية أداء لاعبي التايكوندو، وقد قام الباحث بإستخدام المنهج التجريبي على عينة قوامها (بr) لاعب من لاعبي التايكوندو في المرحلة السنية تحت VV سنة، وقد أشنارت أهم النتائج إلي أن البرنامج التدريبي كان له تأثثراً ايجابياً على المجموعة التجريبية في متغيرات الرشاقة والقوة المميزة بالسرعة والتي بدورها تؤثز على مستوى أداء مهارات الخداع للاعبي التايكوندو . 
تأثير استخدام بعض أساليب الذذاع على فعالية الأداءات الهجومية المركبة لناشئي الكوميتيه في رياضة الكارات

^- أجرى "أحمد محمد حسان" ( 1 • r م)(ع) : بدراسة هدفها التعرف على فاعلية تطوير بعض الموجات الهجومية القطرية على محددات الهجوم ونتائج المباريات لناشئي الكومينيه في رياضة الكاراتيه، وقد استخدم الباحث المنهج التجريبي بتصميم مجموعتين احداهما تجريبية والاخرى ضابطة، على عينه قوامها .ب ناشئ في المرحلة السنية من ع (: 7 أسنه، وكانت أهم

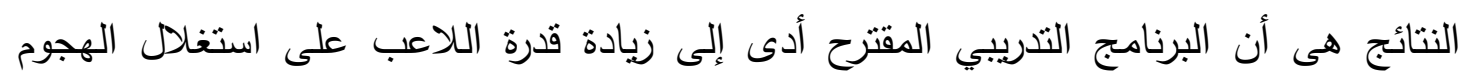
والدفاع في الاتجاهات الرئيسية وال فرعية المختلفة والمتمثلة في الدوائر التذربيية المقترحة، اضافة الى زيادة فعالية الموجات الهجومية أثناء المباريات. منهج البحث:

استخدم الباحث المنهج التجريبي لمناسبتة لطبيعـة البحث وإجراءاته وذلك من خـلال التصميم التجريبي لمجموعتين إحداهما تجريبية والأخرى ضابطة عن طريق القياسبين (القبلي،

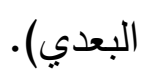
عينة البحث: البعان: تم اختبار عينة البحث بالطريقة العدديـة من ناشئي الكاراتيه بنادي الثبان المسلمين

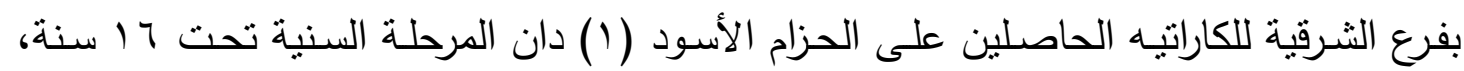

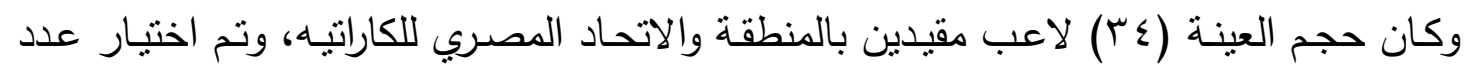

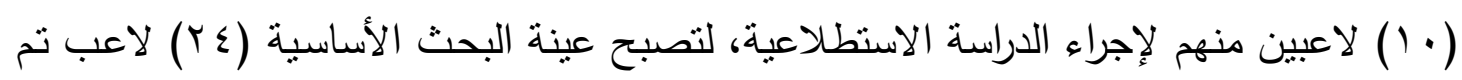
تقسيمهم إلى مجموعتين متساويين إحداهما تجريبية والأخرى ضـابطة قوام كل مجموعة (Y I I ) لاعب حيث تم التكافؤ بينها ويتضح ذلك من خلال جدول رقم: (1).

جدول (1)

تصنيف عينة البحث

\begin{tabular}{|c|c|c|}
\hline النسبة المئويةة & العدد & نوع العينة \\
\hline$\%$ \% rq & ir & مجموعة تجريبية \\
\hline$\%$ \%०. rq & ir & مجموعة ضابطة \\
\hline$\%$ \% $\leqslant Y$ & 1. & مجموعة إستطلاعية \\
\hline$\% 1 \ldots$ & $r \varepsilon$ & المجموع \\
\hline
\end{tabular}

أسباب اختيار عينة البحث:

- إنتظام اللاعبين في التدربب وتوفر العدد الكافي لإجراء البحث.

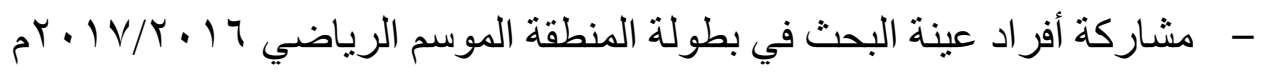
- أفراد عينة البحث حاصلين علي الحزام الأسود ( (1) دان . - تقارب العمر التدريبي للأفراد عينة البحث. 
تأثير استخدام بعض أساليب الخاع على فعالية الأداءات الهجومية المركبة لناثئي الكوميتيه في رياضة الكارات

تجانس عينة البحث:

قام الباحث بإجراء التجانس بين أفراد عينة البحث في متغيرات (السن، إرتقاع القامة، الـوزن، العمـر التدربيجي، فعاليـة بعض أسـاليب الخداع، فعاليـة الأداءات الهجوميـة المركبـة)

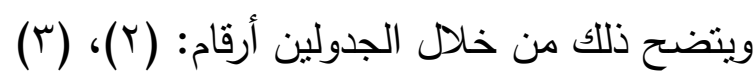

جدول (r)

تجانس أفراد عينة البحث في متغيرات (السن، ارتفاع القامة، الوزن، العمر التديبي) $r \varepsilon=\dot{0}$

\begin{tabular}{|c|c|c|c|c|c|}
\hline معامل الالتواء & الوسيط & الانحراف & المتوسط & وحدة & المتغيرات \\
\hline .01 & 10.9. & $.0 \%$ & $17 . \ldots$ & سنة & السن \\
\hline$\cdots V$ & $179 . \ldots$ & $\varepsilon \ldots$ & $179 . .9$ & سم & ارتقاع القامة \\
\hline$\cdots 99-$ & 01.0. & r.9. & $0 \wedge . \Gamma \wedge$ & كجم & الوزن \\
\hline$. . \wedge 9-$ & v... & 1.89 & $7 . \leqslant V$ & سنة & العمر التدريبي \\
\hline
\end{tabular}

يتضـح مـن جدول (Y) أن جميع قيم معامل الإلتواء لمتغيرات (السن، ارتفاع القامـة،

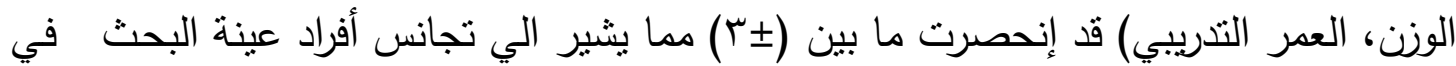

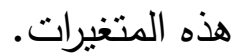

جدول (r)

تجانس أفراد عينة البحث في فعالية بعض أساليب الخداع قيد البحث

$\Gamma \varepsilon=\dot{0}$

\begin{tabular}{|c|c|c|c|c|c|}
\hline الالتواء & الوسبط & المعياري & الحستبي & وحدة القياس & البيان \\
\hline rA.० & .94 & r..०. & 7.09 & rA.0 & أداء خداعي في خط مستقيم \\
\hline$\varepsilon \varepsilon . M Y$ & $. r V-$ & $\leq 0 \ldots$ & $v .00$ & $\varepsilon \varepsilon . M r$ & أداء خداعي قطري \\
\hline rq. \& & $. r \leq-$ & $\varepsilon \ldots$ & V.ru & rq. $\{1$ & أداء خداعي متنوع \\
\hline
\end{tabular}

يتضح من جدول (r) أن جميع قيم معامل الإلتواء في فعالية بعض أساليب الخداع

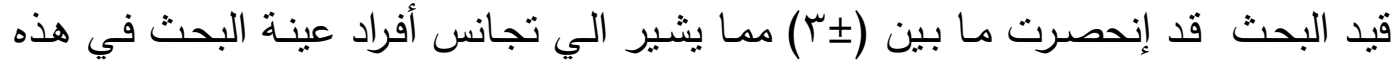

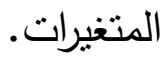


تأثير استخدام بعض أساليب الخاع على فعالية الأداءات الهجومية المركبة لناثئي الكوميتيه في رياضة الكارات

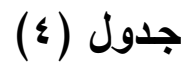

تجانس أفراد عينة البحث في فعالية الأداعات الهجومية المركبة قيد البحث

\begin{tabular}{|c|c|c|c|c|c|}
\hline الالتواء & 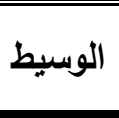 & الإلمعيافي & الحستبط & القياس & 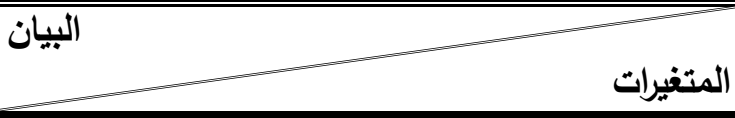 \\
\hline$T r . . r$ & .94 & $7 . .$. & $7 . \leqslant 9$ & $T T_{.} \cdot r^{2}$ & كيزامي زوكي - جياكو زوكي \\
\hline 00.10 & $\cdots \wedge$ & $00 \ldots$ & $0 . v 1$ & 00.10 & جياكو زوكي - كيزامي ماواشي جيري \\
\hline$\varepsilon r . .9$ & $.990-$ & $\leqslant 0 \ldots$ & $7 . . r$ & $\varepsilon r . .9$ & كيزامي زوكي - كيزامي أورا ماواشي جيري \\
\hline พ. $\Sigma \vee$ & $\cdot . \wedge \wedge$ & ro... & $0 .$. & r. $\Sigma V$ & جيزامي زوكي - جياكو زوكي شودان - جياكو زوكي \\
\hline$\varepsilon \varepsilon . Y \uparrow$ &..$V Y$ & $\varepsilon Y .0$. & V.r. & $\varepsilon \varepsilon . Y \uparrow$ & كيزامي زوكي - جياكو زوكي - كيزامي ماواشي جيري \\
\hline
\end{tabular}

يتضح من جدول (ع) أن جميع قيم معامل الالتواء في فعالية الأداءات الهجومية المركبة

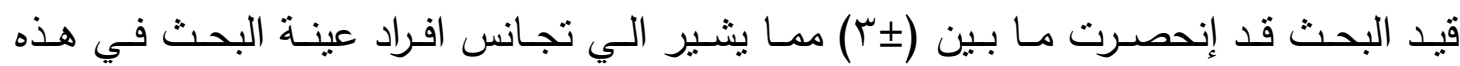

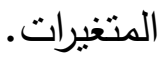

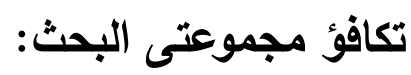

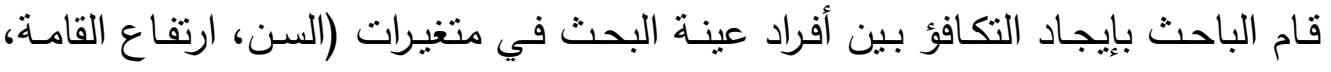

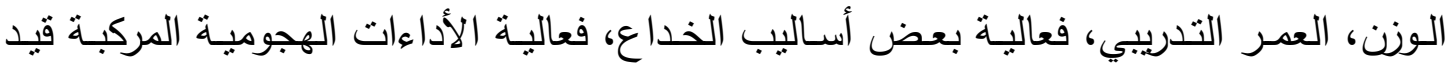

البحث) ويتضح ذللك من خلال جدول رقم: (0).

جدول (ن)

تكافؤ مجموعتي البحث التجريبية والضابطة في (السن، ارتفاع القامة، الوزن، العمر التدريبي) $1 .=r=1$ ن

\begin{tabular}{|c|c|c|c|c|c|}
\hline \multirow{2}{*}{ قيمة (ت) } & \multicolumn{2}{|c|}{ المجموعة الضابطة } & \multicolumn{2}{|c|}{ المجموعة التجريبية } & \multirow[t]{2}{*}{ البيان } \\
\hline & $\varepsilon \pm$ & س - l - l س & $\varepsilon \pm$ & س - ا & \\
\hline I.rr & . . $\varepsilon r$ & 10.94 &..$T r$ & 17.rY & السن \\
\hline. .10 & $r .79$ & $179 . \ldots$ & $r .91$ & $171 . V_{0}$ & ارتقاع القامة \\
\hline .1 & $r . \leqslant \wedge$ & $0 \wedge .01$ & \&.rT & $0 \wedge . \leqslant Y$ & الوزن \\
\hline.$r \xi$ & .9 & $T . \varepsilon Y$ &. $.7 \mathrm{~V}$ & 7.0. & العمر التدريبي \\
\hline
\end{tabular}

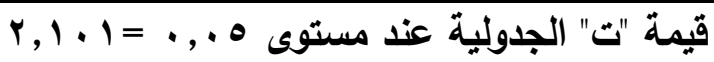

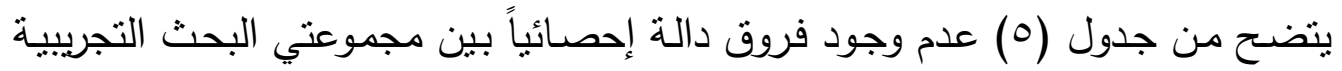

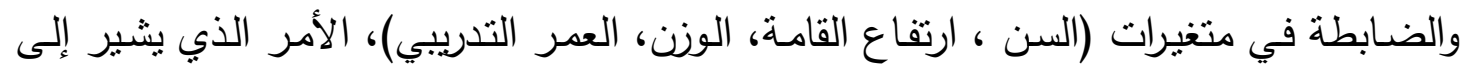
تكافؤ مجموعتي البحث في هذه المتغيرات. 
تأثير استخدام بعض أساليب الخاع على فعالية الأداءات الهجومية المركبة لناثئي الكوميتيه في رياضة الكارات

\section{جدول (7) (7) - (7)}

تكافؤ مجموعتى البحث التجريبية والضابطة في فعالية بعض أساليب الخداع قيد البحث $1 .=r \dot{0}=10$

\begin{tabular}{|c|c|c|c|c|c|}
\hline \multirow[t]{2}{*}{ قيمة (ت) } & \multicolumn{2}{|c|}{ المجموعة الضابطة } & \multicolumn{2}{|c|}{ المجموعة التجريبية } & \multirow[t]{2}{*}{ البيان } \\
\hline & $\varepsilon \pm$ & س & $\varepsilon \pm$ & س " س & \\
\hline. YA & $0 . V \leqslant$ & $r v . \wedge r$ & $7 . \leqslant 0$ & rı.०V & أداء خداعي في خط مستقيم \\
\hline .09 & V.VI & $\varepsilon \varepsilon . \vee 1$ & $7.1 \leqslant$ & $\varepsilon r .97$ & أداء خداعي قطري \\
\hline.$r \wedge$ & V.rY & $\varepsilon \ldots \varepsilon r$ & 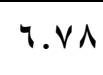 & $\varepsilon 1 . r 0$ & أداء خداعي متتوع \\
\hline
\end{tabular}

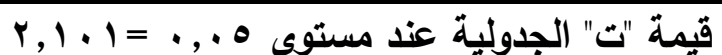

يتضح من جدول (7) عدم وجود فروق دالة إحصائياً بين مجموعتي البحث التجريبية والضابطة في فعالية بعض أساليب الخداع قيد البحث، الأمر الذي يشير إلى تكافؤ مجموعتى البحث في هذه المتغيرات.

\section{جدول (v)}

تكافؤ مجموعتى البحث التجريبية والضابطة في فعالية الأداعات الهجومية المركبة $1 .=r \dot{0}=1 \dot{0}$

\begin{tabular}{|c|c|c|c|c|c|}
\hline \multirow{2}{*}{ 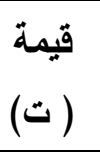 } & \multicolumn{2}{|c|}{ المجموعة الضابطة } & \multicolumn{2}{|c|}{ المجموعة التجريبية } & \multirow{2}{*}{ لمتغيرات } \\
\hline & $\varepsilon \pm$ & س & $\varepsilon \pm$ & س & \\
\hline$\cdot . \leqslant V$ & $v . \cdot r$ & $09.1 \mathrm{~V}$ & $0 . \varepsilon r$ & $7 . . \leqslant r$ & كيزامي زوكي - جياكو زوكي \\
\hline. .17 & $v . \cdot v$ & $00 \ldots$ & $\varepsilon .91$ & $00 . \leqslant r$ & جياكو زوكي - كيزامي ماواشي جيري \\
\hline$\cdot \wedge \varepsilon$ & T.rY & $\varepsilon$ Y.०. & $0 . \varepsilon r$ & $\leq \varepsilon .01$ & كيزامي زوكي - كيزامي أورا ماواشي جيري \\
\hline 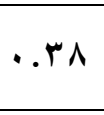 & $0 . \wedge r$ & $r v . . \Lambda$ & \&.r & rq.ro & جودان بنفس زوكي - جياكو زوكي شودان - جياكو زوكي \\
\hline..$r V$ & $\Lambda .+1$ & $\varepsilon r . v \bullet$ & Y.Y. & $\varepsilon r . q r$ & كيزامي زوكي - جياكو زوكي - كيزامي ماواشي جيري \\
\hline
\end{tabular}

يتضح من جدول (V) عدم وجود فروق دالة إحصائياً بين مجموعتى البحث التجريبية والضابطة في فعالية الأداءات الهجومية المركبة قيد البحث، الأمر الذي يثنير إلى تكافؤ مجموعتي البحث في هذه المتغيرات. أدوات ووسائل جمع البيانات:

قام الباحث بتحديد أدوات ووسائل جمع البيانات الخاصة بالبحث من خلال الإطلاع على المراجع العلمية المتخصصة وكذلك الدراسات السابقة وتتضح هذه الوسائل فيما يلي: 
تأثير استخدام بعض أساليب الذذاع على فعالية الأداءات الهجومية المركبة لناشئي الكوميتيه في رياضة الكارات

أولاً: تحليل المباريات: مرفق( ) تم تحليل بعض مباريات بطولة الجمهورية في المرحلة السنية تحت 17 المبات سنه الموسم

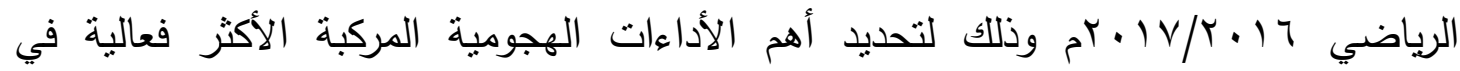

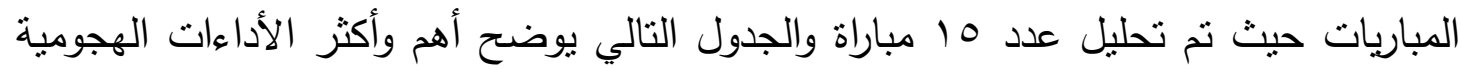
المركبة تكراراً أثناء المباريات حيث تهتيل علد ها أهم نتائج هذا التحليل من خلال جدول رقم (^):

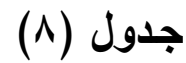

نتيجة تحليل بطولة الجمهورية للناشئين تحت 19 سنه لتحديد أهم الأداعات الهجومية المركبة قيد البحث

\begin{tabular}{|c|c|c|c|}
\hline الترتيب & النسبه & 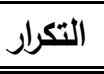 & الأداءات الهجومية المركبة \\
\hline الأول & $\%$ Yr.A & $\Lambda \vee$ & كيزامي زوكي - جياكو زوكي \\
\hline 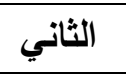 & $\% 10.0$ & 09 & كيزامي زوكي- كيزامي أورا ماواشي جيري \\
\hline الثالث & $\% 1 \leq . \varepsilon$ & 00 & - جياكو زوكي - كيزامي ماواشي جيري \\
\hline الرابع & $\% 11 . r$ & $\varepsilon r$ & كيزامي زوكي - جياكو زوكي شودان - جياكو زوكي جودان \\
\hline 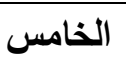 & $\% 1 \cdot . \wedge$ & $\leqslant 1$ & كيزامي زوكي - جياكو زوكي - كيزامي ماواشي جيري \\
\hline
\end{tabular}

ثانياً : قياس فعالية بعض أساليب الخداع قيد البحث:

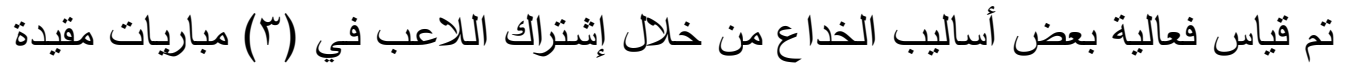
بواجب خداعي محدد لكل مباراة (أداء خداعي في خط مستقيم، أداء خداعي قطري، أداء خداع لـاعي

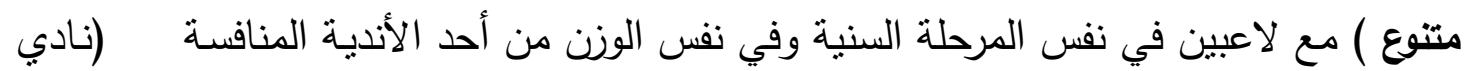

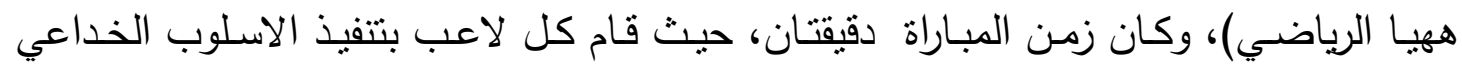

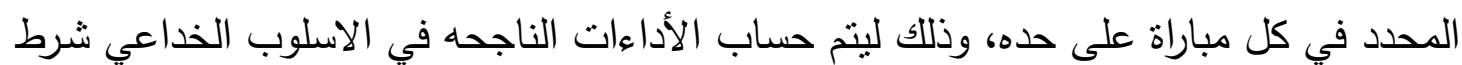
أن يكون سبياً في احراز نقطه.

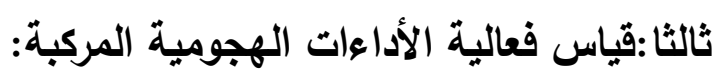

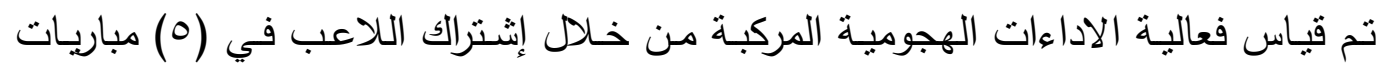

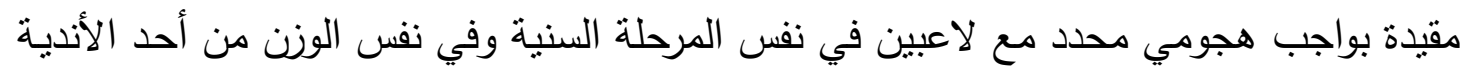

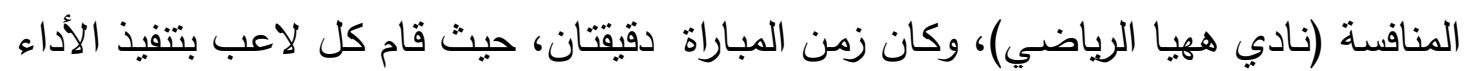

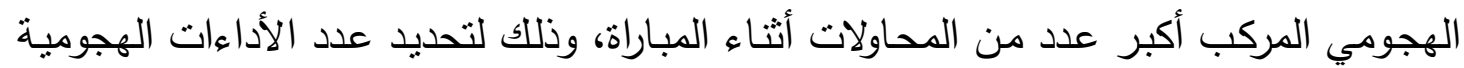

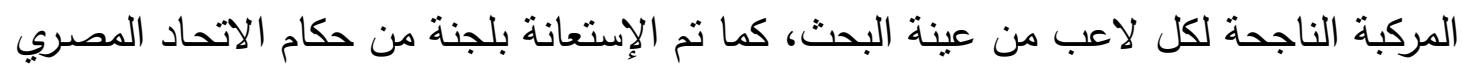
للكاراتيه لإدارة المباريات.

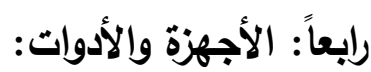

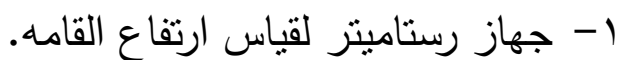

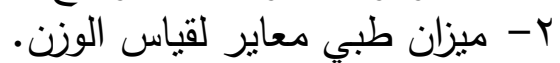

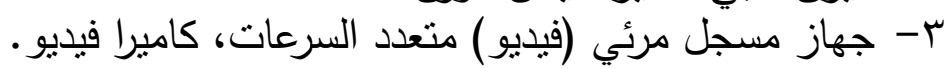

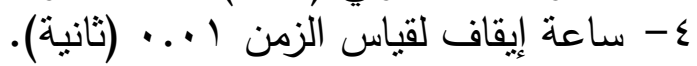


تأثير استخذام بعض أساليب الذذاع على فعالية الأداعات الهجومية المركبة لناثئي الكوميتيه في رياضة الكارات

0- شريط قياس مدرج بالسنتيمثر •

الاراسة الاستطلاعية:

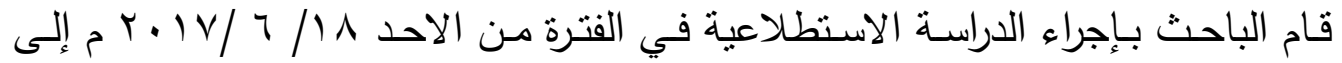

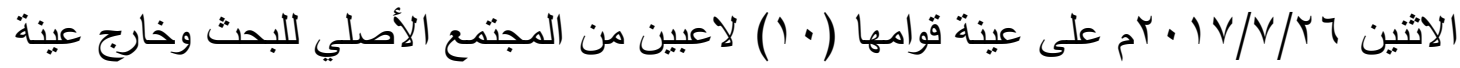

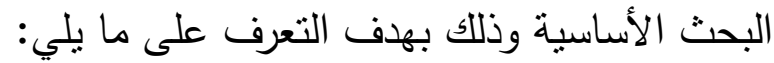

- التأكد من سلامة وصلاحية الأدوات والأجهزة المستخدمة. - تحديد الصعوبات التي تواجه الباحث عند تتفيذ القياسات والاختبارات.

- تحديد الزمن اللازم لتنفيذ القياسات وترتيبها. - تدريب المساعدين على كيفية إجراء الإختبارات والقياسات.

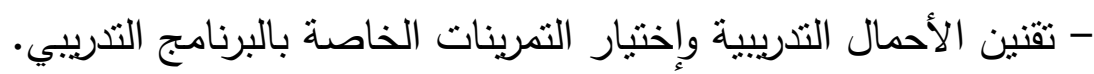
- إجراء المعاملات العلمية (الصدق - الثبات) للاختبارات قيد البحث. بالبه

المعاملات العلمية (الصدق - الثبات) للقياسات قيد البحث: أولاً: الصدق:

قام الباحث بحساب معامل صدق التمايز للقياسات قبد البحث من خلال تطبيق القياسات على مجموعتين إحداهما مميزة قوامها (· ( ) لاعبين حاصلين على الحزام الاسود (1) دان وهى مجموعة من لاعبي الكومينيه تحت 17 سنة حاصلين على بطولة الجمهورية ومجموعة أقل تميزاً قوامها (· (1) لاعبين وهي نفس المجموعة المستخدمة في إيجاد ثبات الإختبارات عن طريق إستخدام نفس بيانات التطبيق الأول لها، وقد تم حساب قيمة "ت" بين المجموعتين المميزة والاقل تميزاً في المتغيرات قيد البحث، ويتضح ذلك من خلال الجدولين

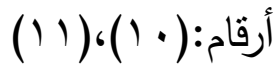

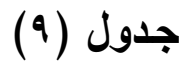

معامل صدق التمايز لفعالية بعض أساليب الخداع قيد البحث

$1 \cdot=r \dot{U}=1 \dot{0}$

\begin{tabular}{|c|c|c|c|c|c|c|}
\hline \multirow{2}{*}{ قيمة (ت) } & \multicolumn{2}{|c|}{ |المجموعة الاقل تميزاً } & \multicolumn{2}{|c|}{ المجموعة المميزة } & \multirow[t]{2}{*}{ البيان } & \\
\hline & $\varepsilon \pm$ & س & $\varepsilon \pm$ & س س & & المتغيرات \\
\hline$* .10$ & 1.19 & rq.r & 7.04 & 0.0 & & أداء خداعي في خط مستقيم \\
\hline$* \varepsilon .19$ & 9.17 & $\leqslant 0.0$. & $v .91$ & Tr.o. & & أداء خداعي قطري \\
\hline$* r .09$ & V.Vo & ז.... & $\varepsilon .1 T$ & $\leq 7.0$. & & أداء خداعي متنوع \\
\hline
\end{tabular}

.دال عند مستوى 0 .,

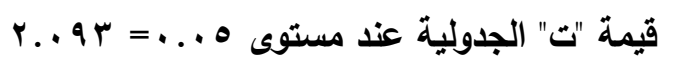


تأثير استخدام بعض أساليب الخاع على فعالية الأداءات الهجومية المركبة لناثئي الكوميتيه في رياضة الكارات

يتضح من جدول (9) وجود فروق دالة إحصائياً بين المجموعتين المميزة والاقل تميزاً ولصالح المجموعة المميزة في فعالية بعض أساليب الخداع قيد البحث، مما يشير إلى صدق هذه

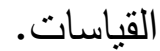

$$
\text { جدول (1.) (1) (1) (1) }
$$

معامل صدق التمايز لفعالية الأداعات الهجومية المركبة قيد البحث

$1 \cdot=r \dot{ن}=1 \dot{0}$

\begin{tabular}{|c|c|c|c|c|c|}
\hline \multirow{2}{*}{ قالمسة (ت) } & \multicolumn{2}{|c|}{ المجموعة الاقل تميزاً } & \multicolumn{2}{|c|}{ المجموعة المميزة } & \multirow{2}{*}{ المتغيرات } \\
\hline & $\varepsilon \pm$ & س & $\varepsilon \pm$ & س & \\
\hline$* r . \vee \varepsilon$ & 7.01 & $\uparrow \varepsilon \ldots$ & $\varepsilon .09$ & $v \leqslant \ldots$ & كيزامي زوكي - جياكو زوكي \\
\hline$* \varepsilon . Y \leq$ & $0 . r V$ & $00 .$. & $\varepsilon . \vee 1$ & $70 .$. & جياكو زوكي - كيزامي ماواشي جيري \\
\hline *Y.YO & 0.10 & $\leq r_{.} \cdot$ & $7 . \leqslant V$ & $\leqslant \wedge .0$ & كيزامي زوكي- كيزامي أورا ماواشي جيري \\
\hline *Y.V^ & 0.17 & r.... & $\varepsilon . \varepsilon r$ & $\varepsilon r . r$. & زوكي جوداني زوكي - جياكو زوكي شودان - باكو \\
\hline$* Y . r \wedge$ & $\vee . \wedge \varepsilon$ & $\leq 7.0$ & $9 . \cdot V$ & $07 . .$. & كيزامي زوكي- جياكو زوكي - كيزامي ماواشي \\
\hline
\end{tabular}

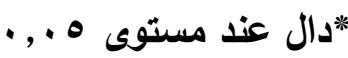

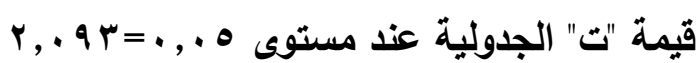

يتضح من جدول (· () وجود فروق دالة إحصائياً بين المجموعتين المميزة والاقل

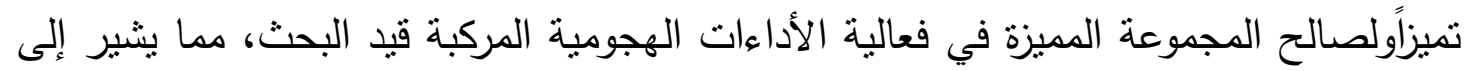

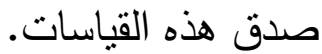

ثانياً: الثبات:

قام الباحث بحساب معامل الثبات بإستخدام طريقة تطبيق القياس وإعادة التطبيق بفارق

زمني (V) ايام ، وذلك على عينة الدراسة الإستطلاعية وعددها ( • () لاعبين من نفس مجتمع

البحث وخارج العينة الأساسية، حيث تم تطبيق هذه القياسات تحت نفس ظروف وشروط

التطبيق الأول، وقد ثم إيجاد معامل الارتباط البسيط بين نتائج التطبيقين الأول والثاني، ويتضح

$$
\text { ذلك من خلال الجدولين أرقام : (1 (1) ، (1) ). }
$$


تأثير استخذام بعض أساليب الذذاع على فعالية الأداءات الهجومية المركبة لناشئي الكوميتيه في رياضة الكارات

$$
\text { جدول (11) }
$$

معامل ثبات فعالية بعض أساليب الخداع قيد البحث

\begin{tabular}{|c|c|c|c|c|c|c|}
\hline \multirow{2}{*}{ قيمة (ر) } & \multicolumn{2}{|c|}{ التطبيق الثانيب } & \multicolumn{2}{|c|}{ التطبيق الأول } & \multirow[t]{2}{*}{ 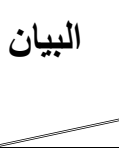 } & \\
\hline & $\varepsilon \pm$ & س & $\varepsilon \pm$ & س - س & & المتغيرات \\
\hline$* .9$ & $7.7 \mathrm{~V}$ & 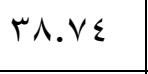 & 1.19 & rq. ए & & أداء خداعي في خط مستقيم \\
\hline$* . .19$ & V.rA & $\leq 7 \ldots$ & 9.17 & $\leq 0.0$ & & أداء خداعي قطري \\
\hline$* . . \wedge 7$ & Q.r & rч.r. & V.Vo & r... & & أداء خداعي متنوع \\
\hline
\end{tabular}

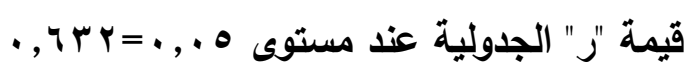

يتضـح من جدول (1) وجود علاقة إرتباطيـة دالة احصـائياً عند مستوى 0 . . · بين

التطبيقين الأول والتطبيق الثاني في فعالية بعض أسـاليب الخداع قيد البحث، وهذا يشير إلي

ثبات هذه القياسات عن اعادة تطبيقها.

\section{جدول (Y I I)}

معامل ثبات فعالية الأداعات الهجومية المركبة قيد البحث

\begin{tabular}{|c|c|c|c|c|c|}
\hline \multirow{2}{*}{ قيمة (ر) } & \multicolumn{2}{|c|}{ التطبيق الثاني } & \multicolumn{2}{|c|}{ التطبيق الأول } & \multirow{2}{*}{ المتغيرات } \\
\hline & $\varepsilon \pm$ & 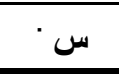 & $\varepsilon \pm$ & س - س & \\
\hline$* . \wedge r$ & $1.7 \leqslant$ & $7 \leq .0$. & 7.01 & $7 \leq \ldots$ & كيزامي زوكي - جياكو زوكي \\
\hline$* . . V$ & 0.99 & 00.0 & $0 . Y V$ & $00 \ldots$ & جياكو زوكي - كيزامي ماواشي جيري \\
\hline$* . \wedge$ & $\mathrm{V} . \mathrm{IV}$ & $\varepsilon r .0$. & $0 . V_{0}$ & $\leq r \ldots$ & كيزامي زوكي- كيزامي أورا ماواشي جيري \\
\hline$* . \vee$ & 7.rY & rv... & 0.17 & r.... & زوكي جودان زوكي - جياكو زوكي شودان - جياكو \\
\hline *.VV & $\Lambda . \leqslant r$ & $\varepsilon 7 .$. & $\vee . \wedge \varepsilon$ & $\leq 4.0$ & كيزامي زوكي - جياكو زوكي - كيزامي ماواشي جيري \\
\hline
\end{tabular}

يتضـح من جدول (Y I) وجود علاقة إرتباطية دالة إحصـائياً عند مستوى 0 . . . بين

التطبيقين الأول والتطبيق الثاني في قياسات فعالية الأداءات الهجومية المركبة قيد البحث، وهذا

يشير الي ثبات هذه القياسات عند إعادة تطبيقها. 
البرنامج التدريبي المقترح: تفصيليا مرفق (0) قام الباحث بإعداد البرنامج التدريبي المقترح وفقاً للأسس العلمية ومن خلال الإطلاع على بعض المراجع العلمية المتخصصة والدراسات السابقة التالية: "أحمد محمود إبراهيم"

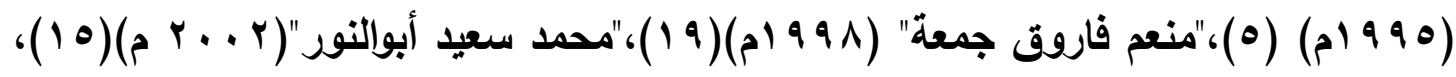

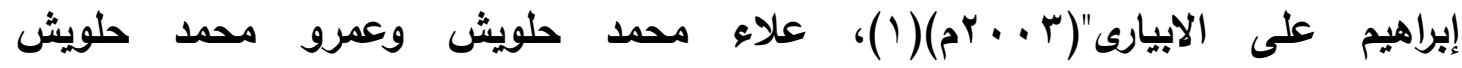

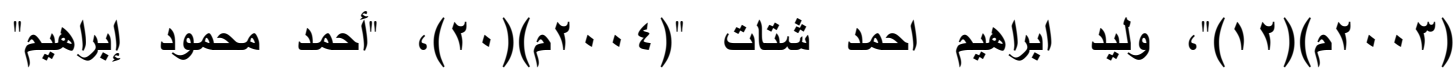

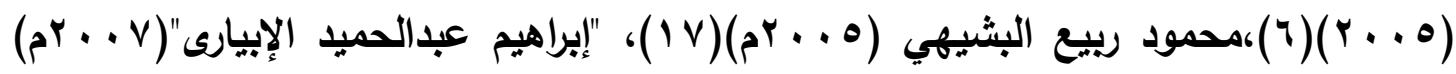

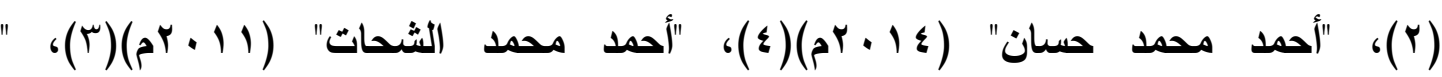

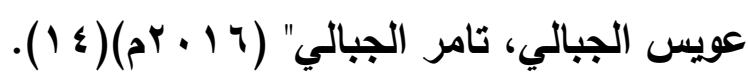

حيث تم تحديد الفترة الزمنية للبرنامج التدربي بواقع اثتى عثر اسبوعا تم تقسيمهم الى

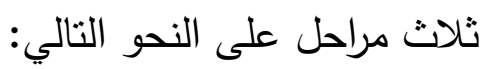
- مرحلة الاعداد العام. ( أسابيع) - مرحلة الاعداد الخاص. (ه أسابيع) - مرحلة ما قبل للمنافسات. (ع أسابيع)

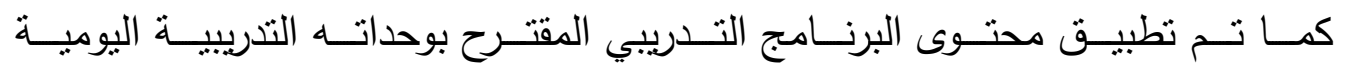
بأجزائهـا المختلفـة (التمهيـدي، الإعـدادي، الرئيسـي، الختـــي) علـى المجمـوعتين التجريبيـة والضـابطة في نفس المكـان والتوقيـت وتحـت ظـروف تدريبيـة منتـابهة بإسـتخدام تمرينـات الإعـداد البـدني الخـاص والإعـداد المهـاري والإعـداد الخططـي بإسـتنثاء تمرينـات الاداءات الخداعية والتي تم إستخدامها مع المجموعة التجريبية فقط

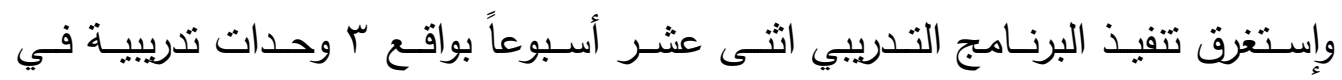

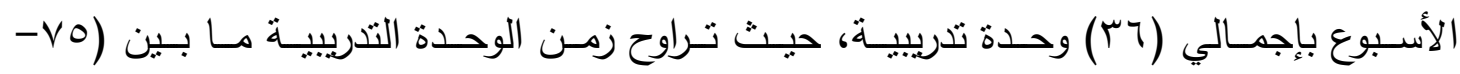

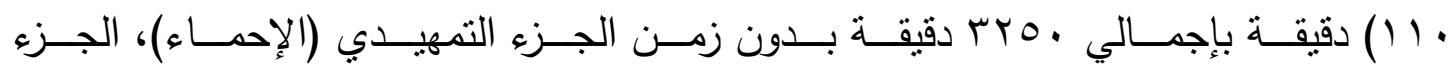

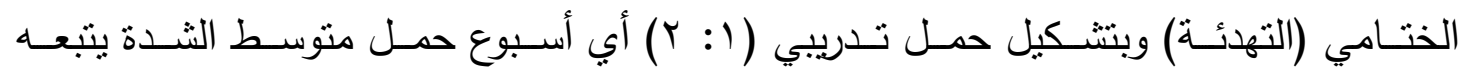

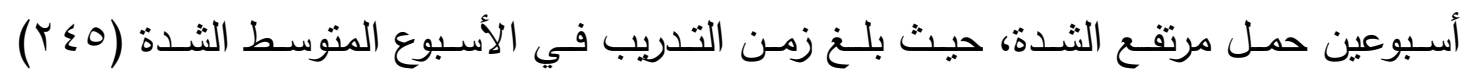
دقيقـة بـدون زمـن الإحمـاء والتهـئه، كمـا بلــن زمـن التـدريب في الأسـبوع ذو الثـدة العاليـة

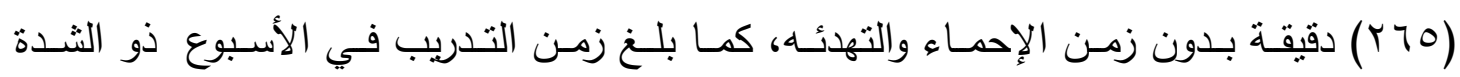

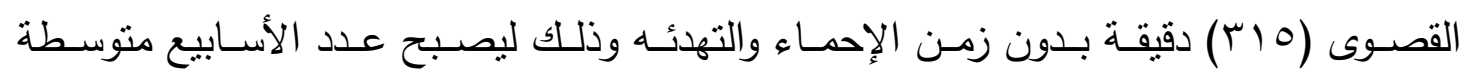


الثـدة (ع) أسـابيع ، وعـد الأسـابيع عاليـة الثـدة (0) أسـابيع، وعـدد الأسـابيع ذات الثـــة

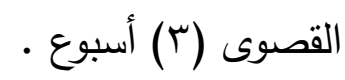

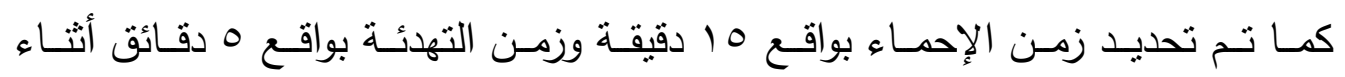

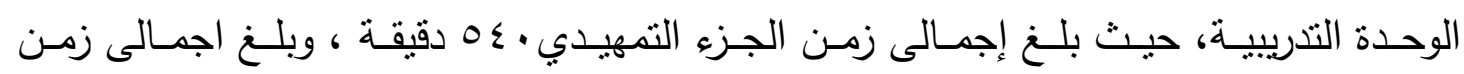

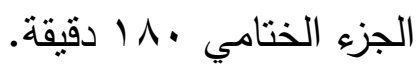

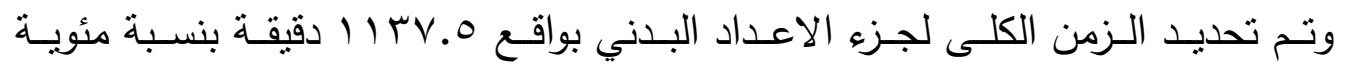
بلغت هr\% من إجمالي زمن البرنامج التشريبي بدون الإحماء والتهدئه.

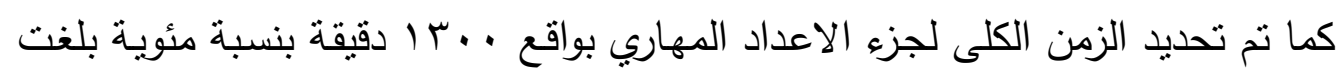
• ـ ٪ من إجمالي زمن البرنامج التنريبي بدون الإحماء والتهيئه.

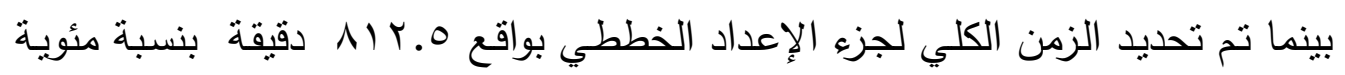
بلغت هب \% من إجمالي زمن البرنامج التدريبي بدون الإحماء والتهدئه.

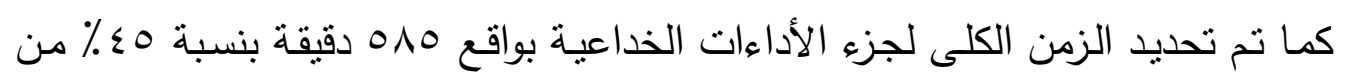

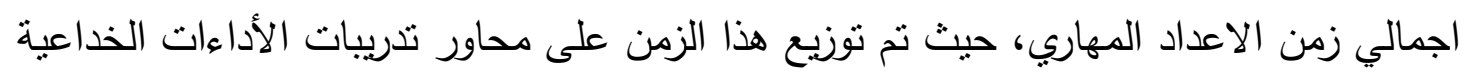

أداعات خداعيـة فـي خط مسـتقيم • ץ\% مـن الزمن المخصص لـلأداءات الخداعيـة

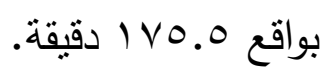

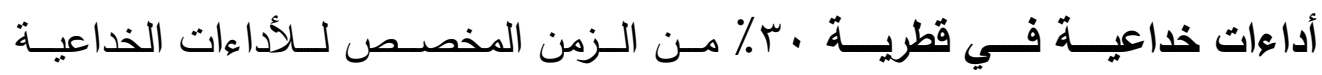

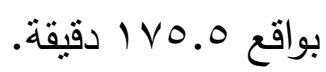

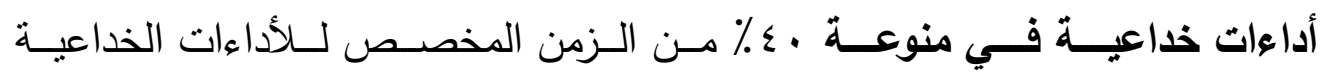
بواقع عr ب دقيقة. 
تأثير استخذام بعض أساليب الذاع على فعالية الأداءات الهجومية المركبة لناثئي الكوميتيه في رياضة الكارات

$$
\text { جدول (T) }
$$

التوزيع الزمني لمتغيرات البرنامج التدريبي المقترح بالنسب المئوية والدقائق

\begin{tabular}{|c|c|c|c|c|c|}
\hline \multicolumn{2}{|c|}{ الإجمالي بالدقيقة } & \multirow{2}{*}{ بالاقيقة } & \multirow{2}{*}{ 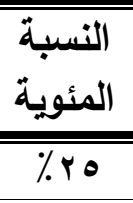 } & \multicolumn{2}{|l|}{ المتغيرات } \\
\hline \multirow{14}{*}{ l } & \multirow{6}{*}{ 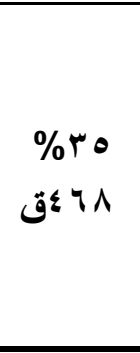 } & & & القوة & \multirow{6}{*}{ الصفاتة العامهة } \\
\hline & & 94.7 & $\% r$ & السرعة & \\
\hline & & 94.7 & $\%$ r. & التحمل & \\
\hline & & $V \cdot r$ & $\% 10$ & المرونة & \\
\hline & & $\leqslant 7 . \wedge$ & $\% 1$. & الرشاقة & \\
\hline & & $\leqslant 7.1$ & $\% 1$ & التوازن & \\
\hline & & IV & $\%$ \% & القوة|لمميزة بالسرعة & \\
\hline & & $1 r \cdot .0$ & $\% 10$ & سرعة الاداء & \\
\hline & & $11 r .1$ & $\%$ ir & الرشاقة & \\
\hline & \%ч० & $1 \cdot \varepsilon . \varepsilon$ & $\% 1 r$ & المرونة & القدرات \\
\hline & ق ^ & $\Lambda \vee$ & $\%$. & تحمل سرعه & البدنية \\
\hline & & $\wedge \vee$ & $\%$. & تحمل قوه & الخاصة \\
\hline & & $\wedge \vee$ & $\% 1$ & تحمل اداء & \\
\hline & & $\Lambda \vee$ & $\%$. & تحمل دورى تنفسي & \\
\hline & & 71.0 & $\% 1 \leq$ & مهارات فربية بالذراعين & \\
\hline & $\%\{\wedge$ & VA.Y & $\% 19$ & مهارات فردية بالرجلين & الأداal \\
\hline & 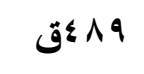 & $\Lambda$. & $\% 1 \wedge$ & مهارات مركبة بالذراعين & \\
\hline $1 \cdot r r$ & & $1 \cdot v .0$ & $\% r r$ & مهارات مركبة بالرجلين & \\
\hline دقيقة & & $1 \leq 7.1$ & $\%$. & مركبة بالذراعين والرجلين & \\
\hline & & 19. & $\% r$ & أداعات خداعية في خط مستقيم & \\
\hline & \%or & 17. & $\%$ & أداعات خداعية في قطرية & الأداع|ت ألات \\
\hline & r & YIT & $\% \varepsilon$. & أداعات خداعية متنوعة & الخذاعيه \\
\hline & & $1 r r .0$ & $\% 10$ & دفاعات & \\
\hline & & $\operatorname{lvA}$ & $\%$ & هجوم خاطف & \\
\hline & & MYY.O & $\%$ ro & هجوم مضاد & النططنة \\
\hline & & rot & $\% \varepsilon$ & مباريات تجريبية & \\
\hline
\end{tabular}


تأثير استخدام بعض أساليب الذاع على فعالية الأداءات الهجومية المركبة لناشئي الكوميتيه في رياضة الكارات

جدول (؛ (1)

التوزيع الزمني للاداعات الخداعية قيد البحث على أسابيع البرنامج بالدقائق

\begin{tabular}{|c|c|c|c|c|c|c|c|c|c|c|c|c|c|}
\hline المجموع & $\begin{array}{l}\text { 可 } \\
3 \\
4 \\
4\end{array}$ & $\begin{array}{l}\bar{y} \\
\bar{y}: \\
y \\
4\end{array}$ & $\overline{3}$ & 哥 & 哥 & 可 & $\frac{\overline{3}}{3}$ & 牙 & $\overline{\overline{3}}$ & 弐 & $\sqrt{\overline{7}}$ & 离 & \\
\hline 17. & & $r$. & & $r 1 . r$ & & $r$. & & Y..1 & & & $r v$ & YO.V & في خط مستقاءيم \\
\hline 19. & YT & & YT & & r. & $r . r$ & & & Y0.T & $\leqslant \Lambda . r$ & - & - & أداءعات خداعية \\
\hline rir & $r$. & Y Q.Y & r. & $r$. & rT.Y & & $\varepsilon V . Y$ & $r . r$ & IY. & - & - & - & أداءات خداعية \\
\hline rroق & or & ०9.Y & $\leq r$ & $01 . Y$ & $\varepsilon r . r$ & $\varepsilon . r$ & $\leq V . r$ & $\leq 7 . r$ & $\mu \wedge$ & $\varepsilon \Lambda . Y$ & rv & Yo.V & الإجمالي \\
\hline
\end{tabular}

يوضح جدول (ع () التوزيع الزمني لمتغيرات للاداءات الخداعية قبد البحث على أسابيع البرنامج

بالأدقائق

جدول (10)

التوزيع الزمني للاداعات الخداعية قيد البحث على الوحدات التدريبية

\begin{tabular}{|c|c|c|c|c|c|c|c|c|}
\hline المجموع & الجمعة & الخميس & الأربعاء & الثلاثاء & الاثثين & الأحد & السبت & \\
\hline ro.V & - & 8.7 & - & 8.5 & - & 8.5 & - & الأول \\
\hline rv & - & 13 & - & 12 & - & 12 & - & الثاني \\
\hline$\varepsilon \Lambda . Y$ & - & 16.2 & - & 16 & - & 16 & - & الثالث \\
\hline$r \wedge$ & - & 12.4 & - & 12.6 & - & 12 & - & الرابع \\
\hline$\varepsilon \% . r$ & - & 20.2 & - & 13.1 & - & 13 & - & الخامس \\
\hline$\varepsilon V . r$ & - & 16 & - & 16 & - & 15.2 & - & السادس \\
\hline$\varepsilon \cdot r$ & - & 20 & - & 10.2 & - & 10 & - & السابع \\
\hline$\varepsilon r . r$ & - & 23.2 & - & 10 & - & 10 & - & الثامن \\
\hline $01 . r$ & - & 30 & - & 11 & - & 10.2 & - & التاسع \\
\hline$\varepsilon r$ & - & 20 & - & 13 & - & 10 & - & العاشر \\
\hline $09 . Y$ & - & 29.2 & - & 15 & - & 15 & - & الحادي عشر \\
\hline or & -- & 30 & -- & 13 & -- & 10 & -- & الثاني عشر \\
\hline rro & & & & & & & & المجموع \\
\hline
\end{tabular}

يوضح جدول (0 ) زمن التوزيع الزمني الاداءات الخداعية قيد البحث خلال الوحدات التدريبي

مجلة بحوث التربية الثاملة ـ كلية التربية الرياضية للبنات ـ جامعة الزقازيق ـ المجلد الأول ـ للنصف الأول للأبحاث العلمية _ـ I ـ بم 
تأثير استخذام بعض أساليب الخداع على فعالية الأداءات الهجومية المركبة لناشئي الكوميتيه في رياضة الكارات

جدول (1 14

نموذج من وحدة تدريبية مطبقة على المجموعة التجريبية

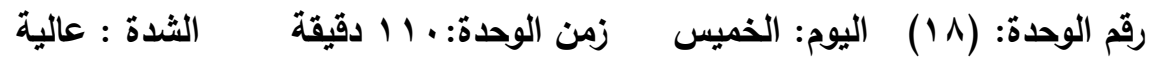

\begin{tabular}{|c|c|c|c|c|c|c|c|c|c|c|}
\hline \multirow{2}{*}{ زالتمرين } & \multirow{2}{*}{ الكثافة } & \multirow{2}{*}{ زالراحة } & \multicolumn{2}{|c|}{ الحجم } & \multirow{2}{*}{ نبض القب } & \multirow[b]{2}{*}{ |الشدة | } & \multirow{2}{*}{ هدف التمرين } & \multirow{2}{*}{ التمرين } & \multirow{2}{*}{ الوحدة } & \multirow{2}{*}{ الوحدة } \\
\hline & & & مجموعات & التكرار زمن & & & & & & \\
\hline ثr... & - & - & 1 & \multirow{5}{*}{ ثعدي } & \multirow{5}{*}{ 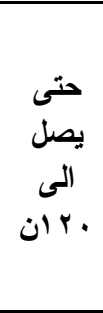 } & \multirow{5}{*}{ 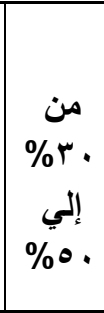 } & \multirow{5}{*}{ التبانيئة } & 1 & \multirow{5}{*}{ (ه إق) } & \multirow{5}{*}{ التمهيء } \\
\hline ث1. & - & - & 1 & & & & & $r$ & & \\
\hline ث1 & - & - & 1 & & & & & 0 & & \\
\hline ثr. & - & - & 1 & & & & & v & & \\
\hline H. & - & - & 1 & & & & & 9 & & \\
\hline . צrث. & $r: 1$ & . & $\varepsilon$ & . & \multirow{3}{*}{-} & \multirow{3}{*}{$\% \wedge$. } & \multirow{3}{*}{ مرونة } & $r$ & \multirow{10}{*}{ بدرات } & \multirow{10}{*}{ لاعدادي } \\
\hline . צrث. & $r: 1$ & r. & $\varepsilon$ & . rث & & & & 7 & & \\
\hline . צrث. & $r: 1$ & . & $\varepsilon$ & . & & & & $\wedge$ & & \\
\hline . & $r: 1$ & . & $\varepsilon$ & . & \multirow{4}{*}{ ع V V } & \multirow{4}{*}{$\% \wedge$. } & \multirow{4}{*}{ رشاقه } & $\wedge$ & & \\
\hline . צ"ث. & $r: 1$ & ז. & $\varepsilon$ & . & & & & 9 & & \\
\hline . ז"ث. & $r: 1$ & . & $\varepsilon$ & . & & & & 11 & & \\
\hline צr"ث. & $r: 1$ & . & $\varepsilon$ & . & & & & ir & & \\
\hline Brro & $r: 1$ & . & 0 & ه & \multirow{3}{*}{ 47 ان } & \multirow{3}{*}{$\% \vee 0$} & \multirow{3}{*}{ قوالسرعهة مميزه } & $r$ & & \\
\hline EYro & $r: 1$ & . & 0 & ه & & & & 0 & & \\
\hline ثrro & $r: 1$ & . & 0 & ه اث & & & & 9 & & \\
\hline$\dot{ث} \leqslant \Lambda$. & $r: 1$ & $\leftrightarrow \wedge$. & $\varepsilon$ & ـ ع & \multirow{4}{*}{ ع Vان } & \multirow{4}{*}{$\% \wedge$. } & \multirow{4}{*}{ مجومية } & 7 & \multirow{4}{*}{ هركية } & \\
\hline$\dot{ث} \leqslant \Lambda$. & $r: 1$ & $\dot{ث}$. & $\varepsilon$ & . & & & & 0 & & \\
\hline$\dot{ث} \leqslant \Lambda$. & $r: 1$ & $\dot{ث}$ & $\varepsilon$ & . & & & & $\varepsilon$ & & \\
\hline$\dot{ث} \leqslant \Lambda$. & $r: 1$ & ث. & $\varepsilon$ & ـ ـ & & & & v & & الجزء \\
\hline$\dot{ث} \leqslant 90$ & $r: 1$ & ث1. & $r$ & ه० & & & لادات & rq & أداعات & الرئيسي \\
\hline$ث \leqslant 90$ & $r: 1$ & ڤ1. & $r$ & ث0 & ع Vان & $\% \wedge$. & خداعية & $r v$ & خداعية & \\
\hline$\exists \leqslant 90$ & $r: 1$ & ثا & $r$ & ه & & & متنوعة & rs & 1 1 ق & \\
\hline H. & - & - & 1 & . & اقل & أقل & العودة & 0 & التهائة & الجزء \\
\hline$\dot{ث} \wedge$. & - & - & 1 & ث^. & . & $\%$ \%. & الطبيعية & $\wedge$ & (ق) & مي \\
\hline
\end{tabular}

مجلة بحوث التربية الثاملة ـ كلية التربية الرياضية للبنات - جامعة الزقازيق ـ المجلد الأول ـ للنصف الأول للأبحاث العمية _N ا ـ مم 


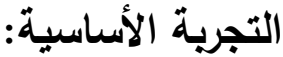

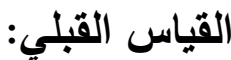

قام الباحث بإجراء القياس القبلي علي عينه البحث في المتغيرات قيد البحث يوم السبت

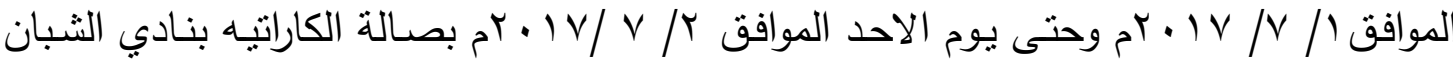

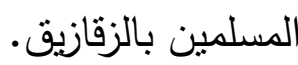

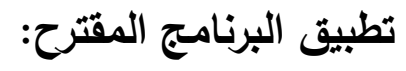
قام الباحث بتطبيق برنامج التدريبات المقترحة على عينه البحث وذلك في الفترة من

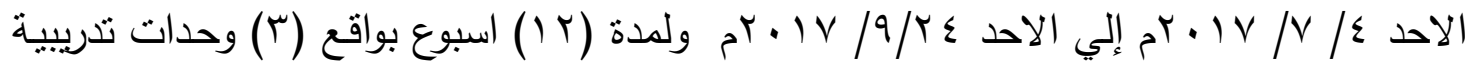
في الاسبوع بإجمالي (؟r) وحدة تدريبية، بصالة الكاراتيه بنادي الثبان المسلمين بالزقازيق.

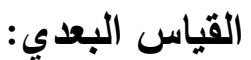

قام الباحث بإجراء القياس البعدي علي عينه البحث في المتغيرات قيد البحث يوم الثلاثاء

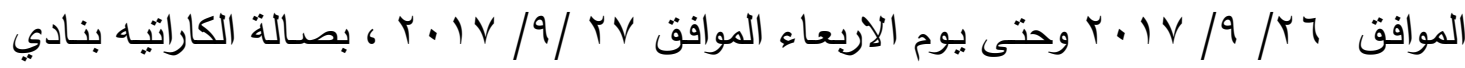
الثبان المسلمين بالزقازيق.، حيث تم تطبيق نفس القياسات التي تم اجرائها في القياس القبلي بنفس الثروط التي تمت في القياس القبلي وتم تفريخ البيانات في إستمارات معدة لذلك تمهيداً لمعالجتها إحصائياً.

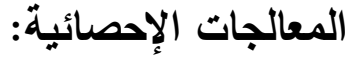

اسـتخدم الباحث حزمـة البرنـامج الاحصـائى للبحـوث والعلـوم الاجتماعيـة(spss) فى المعالجات الاحصائية للبيانات باستخدام:

Arithmetic Average

Standard deviation

Sper man

T. test

Equivalent percentage of improvemene

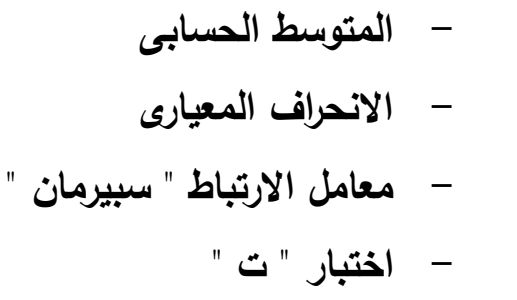

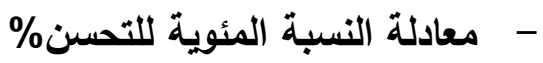

عرض ومناقشة النتائج: 
تأثير استخذام بعض أساليب الذاع على فعالية الأداءات الهجومية المركبة لناشئي الكوميتيه في رياضة الكارات

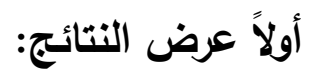

جدول (iv)

دلالة الفروق بين القياسين القبلي والبعدي للمجموعة التجريبية

في فعالية أساليب الخداع قيد البحث

I $r=\dot{0}$

\begin{tabular}{|c|c|c|c|c|c|}
\hline \multirow{2}{*}{ قيمة "ت" } & \multicolumn{2}{|c|}{ القياس البعدي } & \multicolumn{2}{|c|}{ القياس القبلي } & \multirow{2}{*}{ المتغيرات } \\
\hline & $\varepsilon \pm$ & س " & $\varepsilon \pm$ & س " & \\
\hline$* 0.0$. & \&.or & 01.74 & $7 . \leqslant 0$ & rA.०V & أداء خداعي في خط مستقيم \\
\hline$* \vee . q 1$ & r.74 & $7 \ldots$ & $7.1 \varepsilon$ & $\varepsilon Y .97$ & أداء خداعي قطري \\
\hline$* 0 . \mu \wedge$ & $r . . v$ & r.r. & 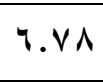 & $\leqslant 1 .{ }^{\prime}$ & أداء خداعي متنوع \\
\hline
\end{tabular}

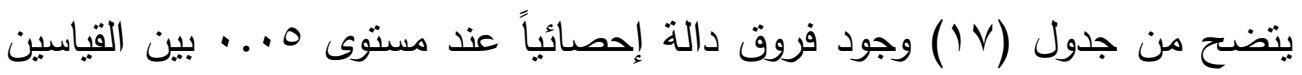

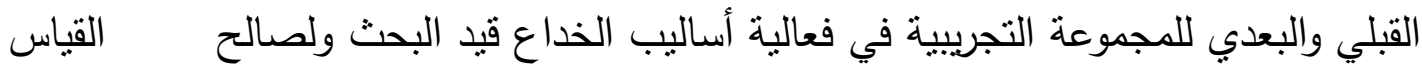

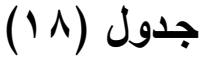

دلالة الفروق بين القياسين القبلي والبعدي للمجموعة التجرئة التجيبية

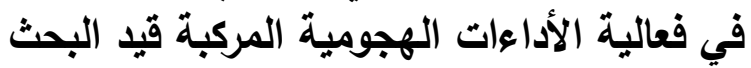

$1 Y=\dot{0}$

\begin{tabular}{|c|c|c|c|c|c|}
\hline \multirow{2}{*}{ قيمة (ت) } & \multicolumn{2}{|c|}{ القياس البعدي } & \multicolumn{2}{|c|}{ القياس القبلي } & \multirow[t]{2}{*}{ 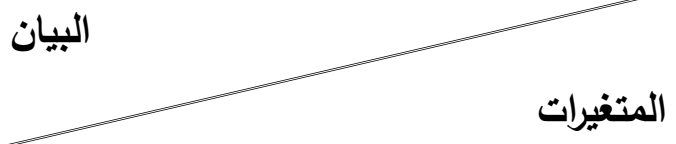 } \\
\hline & $\varepsilon \pm$ & س & $\varepsilon \pm$ & س & \\
\hline$* V . \diamond \mathrm{V}$ & $0 . \varepsilon r$ & $V V .9 r$ & $0 . \leqslant r$ & $9 . . \leqslant Y$ & كيزامي زوكي - جياكو زوكي \\
\hline$* \wedge . \wedge \neg$ & $1 . \wedge r$ & 79.01 & $\varepsilon .91$ & $00 . \leqslant Y$ & جياكو زوكي - كيزامي ماواشي جيري \\
\hline$* \vee . \varepsilon$. & $1 . \varepsilon r$ & $\Delta \vee . \wedge$ & $0 . \leqslant Y$ & $\varepsilon \varepsilon . \diamond \wedge$ & كيزامي زوكي- كيزامي أورا ماواشي جيري \\
\hline$* 9 . Y 1$ & r. $\varepsilon$. & $0 \ldots$ & $\varepsilon . r \mu$ & M.Yo & زوكي جودان بنفي - جياكو زالذوكي شودان - جياكو \\
\hline$* 0 . \wedge$ & $r .9 r$ & $0 \leq .1 \mathrm{~V}$ & T.r. & $\varepsilon r .9 r$ & كيزامي زوكي - جياكو زوكي - كيزامي ماواثثي \\
\hline
\end{tabular}

يتضح من جدول (1) (1) وجود فروق دالة إحصائياً عند مستوى ه ه. . • بين القياسين القبلي

والبعدي للمجموعة التجريبية في فعالية الأداءات الهجومية المركبة ولصالح القياس البعدي.

جدول (19)

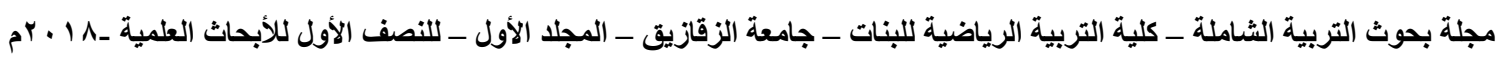


تأثير استخذام بعض أساليب الذاع على فعالية الأداءات الهجومية المركبة لناشئي الكوميتيه في رياضة الكارات

دلالة الفروق بين القياسين القبلي والبعدي للمجموعة الضابطة

في فعالية أساليب الخداع قين البحث

$1 \cdot=\dot{0}$

\begin{tabular}{|c|c|c|c|c|c|}
\hline \multirow{2}{*}{ قيمة "ت } & \multicolumn{2}{|c|}{ القياس البعدي } & \multicolumn{2}{|c|}{ القياس القبلي } & \multirow[t]{2}{*}{ البيان } \\
\hline & $\varepsilon \pm$ & 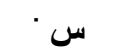 & $\varepsilon \pm$ & 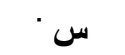 & \\
\hline$* \varepsilon . \varepsilon$. & 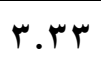 & $\varepsilon 7.7 \%$ & $0 . V \varepsilon$ & rV.Ar & أداء خداعي في خط مستقيم \\
\hline * & Y.EY & Or.qY & V.VI & $\varepsilon \varepsilon . V 1$ & أداء خداعي قطري \\
\hline *Y.A० & r.Ar & $\varepsilon V . . \Lambda$ & V.rY & $\varepsilon \ldots \varepsilon r$ & أداء خداعى متتوع \\
\hline
\end{tabular}

بتضح من جدول (9 1) وجود فروق دالة إحصائياً عند مستوى 0 .. • بين القياسين

القبلي والبعدي للمجموعة الضابطة في فعالية أساليب الخداع قيد البحث ولصالح القياس البعدي.

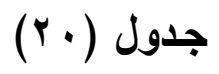

دلالة الفروق بين القياسين القبلي والبعدي للمجموعة الضابطة

في فعالية الأداعات الهجومية المركبة

$1 \cdot=\dot{0}$

\begin{tabular}{|c|c|c|c|c|c|}
\hline \multirow{2}{*}{ قيمة } & \multicolumn{2}{|c|}{ القياس البعدي } & \multicolumn{2}{|c|}{ القياس القبلي } & \multirow{2}{*}{ المتغيرات } \\
\hline & $\varepsilon \pm$ & 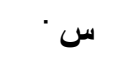 & $\varepsilon \pm$ & س & \\
\hline *\%.^. & T.Y. & $7 V . \cdot 1$ & $V . . r$ & $09.1 \mathrm{~V}$ & (كيزامي زوكي - جياكو زوكي) \\
\hline$* r . \wedge 1$ & $r .79$ & $7 \varepsilon .1 V$ & $v . \cdot v$ & $00 .$. & (جياكو زوكي - كيزامي ماواشي جيري) \\
\hline$* \varepsilon . \wedge 0$ & 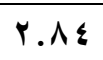 & Or.o. & T.YY & $\varepsilon$ Y.O. & (كيزامي زوكي- كيزامي أورا ماواشي جيري) \\
\hline$r$ & Y.07 & $\leqslant \vee . \wedge \Lambda$ & $0 . \wedge r$ & $r v . \wedge$ & جودان بنفس زلوكي- جياكو زوكي شودان - جياكو زوكي \\
\hline$* Y . \vee \wedge$ & r.79 & $0 . \Delta r$ & A..1 & $\varepsilon r . \vee \theta$ & (كيزامي زوكي- جياكو زوكي - كيزامي ماواشي) \\
\hline
\end{tabular}

يتضح من جدول (·r) وجود فروق دالة إحصائياً عند مستوى 0 . . • بين القياسين القبلي والبعدي للمجموعة الضابطة في فعالية الأداءات الهجومية المركبة ولصالح القياس البعدي.

جدول (r) (r)

مجلة بحوث التربية الثاملة ـ كلية التربية الرياضية للبنات - جامعة الزقازيق ـ المجلد الأول ـ للنصف الأول للأبحاث العمية _N ا ـ مم 
تأثير استخذام بعض أساليب الذاع على فعالية الأداءات الهجومية المركبة لناشئي الكوميتيه في رياضة الكارات

دلالة الفروق بين القياسين البعديين للمجموعتين التجريبية والضابطة في فعالية أساليب الخداع قيد البحث

\begin{tabular}{|c|c|c|c|c|c|}
\hline \multirow{2}{*}{ ق قيمة "ت" } & \multicolumn{2}{|c|}{ المجموعة الضابطة } & \multicolumn{2}{|c|}{ المجموعة التجريبية } & \multirow{2}{*}{ المتغيرات } \\
\hline & $\varepsilon \pm$ & س س & $\varepsilon \pm$ & س & \\
\hline$* Y .90$ & $\varepsilon . \Delta r$ & 01.74 & r.ru & $\varepsilon 7.7 \%$ & أداء خداعي في خط مستقيم \\
\hline$* 0 . M \Delta$ & r.79 & $9 \ldots$ & $r . \varepsilon Y$ & Or.ar & أداء خداعي قطري \\
\hline$* \varepsilon .9 V$ & $r . . v$ & or.rr & r.Ar & $\varepsilon v . . \wedge$ & أداء خداعي متنوع \\
\hline
\end{tabular}

يتضح من جدول (Yl) وجود فروق دالة إحصائياً عند مستوى 0 . . . بين القياسين البعديين للمجموعتين التجريبية والضابطة في فعالية أساليب الخداع قيد البحث ولصالح المجموعة التجريبية.

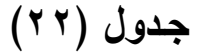

دلالة الفروق بين القياسين البعديين للمجموعتين التجريبية والضابطة

في فعالية الأداعات الهجومية البعنية المركبة لإنمية

\begin{tabular}{|c|c|c|c|c|c|}
\hline \multirow{2}{*}{ 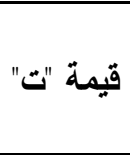 } & \multicolumn{2}{|c|}{ المجموعة الضابطة } & \multicolumn{2}{|c|}{ المجموعة التجرييية } & \multirow{2}{*}{ المتغيرات } \\
\hline & $\varepsilon \pm$ & 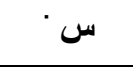 & $\varepsilon \pm$ & 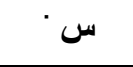 & \\
\hline$* \varepsilon . r V$ & $0 . \leqslant r$ & VV.qr & १.r. & $9 V . .1$ & (كيزامي زوكي - جياكو زوكي) \\
\hline$*$ \&.r & l. $1 \mathrm{r}$ & 79.01 & $r .79$ & $7 \leq .1 V$ & (جياكو زوكي - كيزامي ماواشي جيري) \\
\hline$* \varepsilon . \vee \wedge$ & $1 . \leqslant r$ & $\Delta v . .1$ & Y.^ $\varepsilon$ & or.o. & (كيزامي زوكي- كيزامي أورا ماواشي جيري) \\
\hline$* \varphi . \vee ५$ & Y.\&. & $0 \ldots$ & Y.07 & $\varepsilon V . . \wedge$ & جودان بنفس زوكي - جياكو زوكي شودان - جياكو زوكي \\
\hline *Y.rr & $r .94$ & $0 \leq .1 \mathrm{~V}$ & $r .79$ & $0 . . \wedge r$ & (كيزامي زوكي - جياكو زوكي- كيزامي ماواشي) \\
\hline
\end{tabular}

يتضح من جدول (YY) وجود فروق دالة إحصائياً عند مستوى ه . . بين القياسين البعديين للمجموعتين التجريبية والضابطة في فعالية الأداءات الهجومية المركبة ولصالح المجموعة التجرببية.

\section{جدول (Yr)}

مجلة بحوث التربية الثاملة ـ كلية التربية الرياضية للبنات ـ جامعة الزقازيق ـ المجلد الأول ـ للنصف الأول للأبحاث العلمية _ـ I ـ بم 
تأثير استخذام بعض أساليب الذاع على فعالية الأداءات الهجومية المركبة لناشئي الكوميتيه في رياضة الكارات

نسب التحسن بين القياسات القبلية والبعدية لمجموعتي البحث (التجريبية والضابطة)

في أساليب الخداع والأداعات الهجومية المركبة

\begin{tabular}{|c|c|c|c|c|c|c|c|}
\hline \multirow{2}{*}{ الفروق في } & \multirow{2}{*}{ 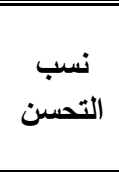 } & \multicolumn{2}{|c|}{ المجموعة الضابطة } & \multicolumn{3}{|c|}{ المجموعة التجريبية } & \multirow{2}{*}{ 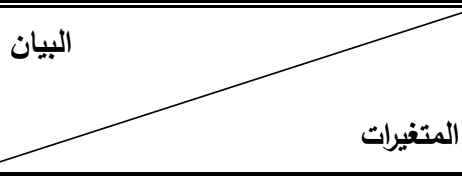 } \\
\hline & & 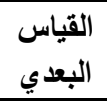 & القباس & التحسنة & البعدي & القباس & \\
\hline$\% 1 \cdot .7$ & \% & $\varepsilon 7.74$ & rV.Ar & \% & $01.7 \pi$ & rᄉ.OV & أداء خداعي في خط مستقيم \\
\hline \%.r.r. & \%) & or.9r & $\varepsilon \varepsilon . \vee 1$ & $\% \% 9.77$ & $7 \ldots$ & $\leqslant Y .97$ & أداء خداعي قطري \\
\hline$\%$ \%.^. & $\% 17 . \varepsilon \wedge$ & $\Sigma \vee . \cdot \wedge$ & $\varepsilon \cdot . \Sigma Y$ & \%ัя.หA & Tr.tr & $\sum 1 . Y_{0}$ & أداء خداعي متنوع \\
\hline$\% 10.09$ & \%IT.TV & $7 V . .1$ & $09.1 \mathrm{~V}$ & $\% \curlyvee \wedge .97$ & $V V .9 Y$ & $7 . . \leqslant Y$ & كيزامي زوكي - جياكو زوكي \\
\hline$\% \wedge . \wedge \wedge$ & $\% 17.7 \mathrm{~V}$ & $7 \varepsilon .1 V$ & $00 \ldots$ & $\%$ \% 0.00 & 79.01 & $00 . \varepsilon r$ & جياكو زوكي - كيزامي ماواشي جيري \\
\hline$\% \leqslant .01$ & \%Yr.or & or.o. & $\leqslant$ Y.O. & 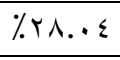 & ov..1 & $\varepsilon \varepsilon .01$ & كيزامي زوكي- كيزامي أورا ماواشي جيري \\
\hline$\% 1 \cdot .97$ & 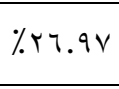 & $\sum V_{.} \cdot \Lambda$ & $r v . . \wedge$ & $\% r v .9 r$ & $0 . \ldots$ & r.to & 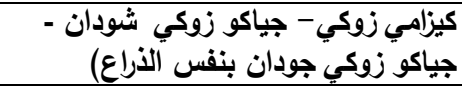 \\
\hline$\% 1 \cdot . r$ & $\% 17.11$ & $0 . . \wedge r$ & $\varepsilon r . V_{0}$ & \%หr.YI & $0 \leq .1 V$ & $\varepsilon r .94$ & ماواشئي زوكي - جياكو زوكي - كيزامي \\
\hline
\end{tabular}

يتضـح من جدول (Tr) وجود فروق في نسب التحسن بين القياسـات القبلية والبعديـة

لكل من مجموعتى البحث (التجريبية والضـابطة) ولصالح المجموعة التجريبية في حيث تراوحت

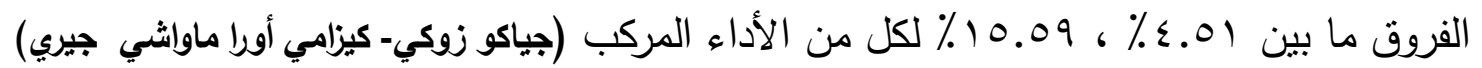

، (كيزامي زوكي - جياكو زوكي).

ثانياً مناقشة النتائج:

في ضـوء هدف البحث وفروضـه وفي حدود عينـة البحث وإجراءاته والنتائج التي تم

التوصل اليها ومن خلال الإعتماد علي المراجع العلمية والدراسات السابقة تم مناقثـة النتائج وفقاً لترتيب فروض البحث علي النحو التالي:

مناقشة نتائج الفرض الأول:

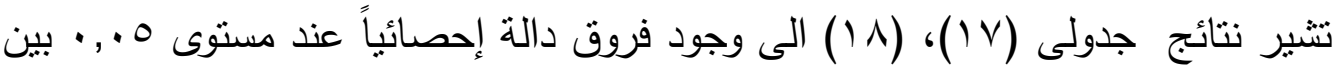
القياسين القبلي والبعدي للمجموعة التجربيية في فعالية أساليب الخداع وفعالية الأداءات الهجومية المركبة قيد البحث ولصالح القياس البعدي، وقد إنحصرت قيم (ت) المحسوبة ما بين (ر؟.0، 1. (Y.9) في الأداء الهجومي المركب (كيزامي زوكي - جياكو زوكي - كيزامي ماواشي) ، (كيزامي زوكي - جياكو زوكي شودان - جياكو زوكي جودان بنفس الذراع)، حيث كانت قيمة (ت) المحسوبة أكبر من قيمة (ت) الجدولية، إضافة إلي وجود نسب تحسن تتضح من خلال جدول

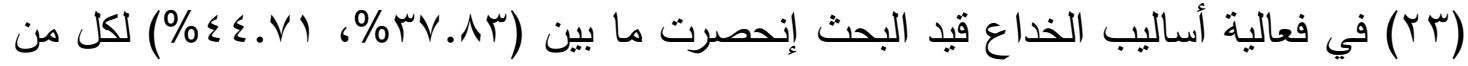


فعالية ألاداء الخداعي في خط مسنقيم ، وفعالية الاداء الخداعي القطري، وفي فعالية الاداءات

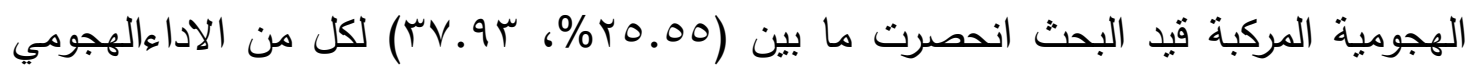

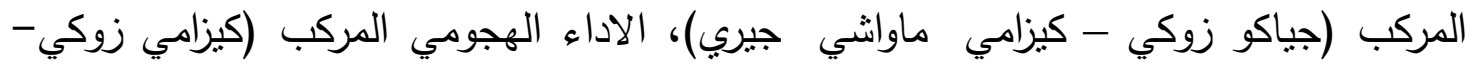
جياكو زوكي شودان - جياكو زوكي جودان بنفس الذراع).

ويرجع الباحث هذه الفروق بين القياسين القبلي والبعدي للمجموعة التجريبية في فعالية

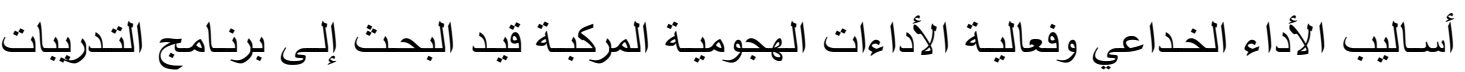

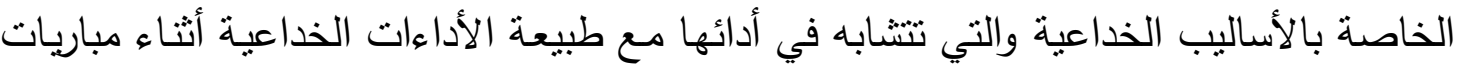

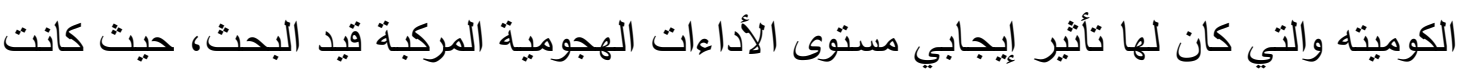

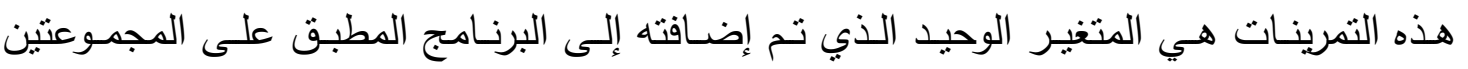

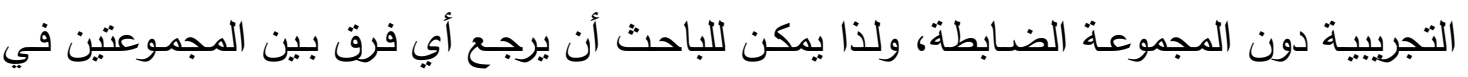

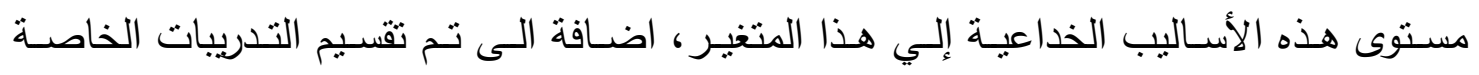

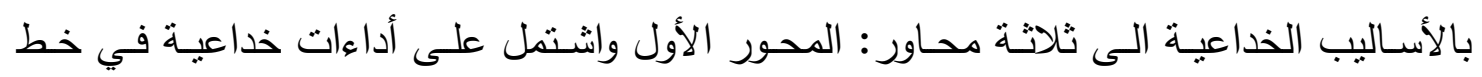

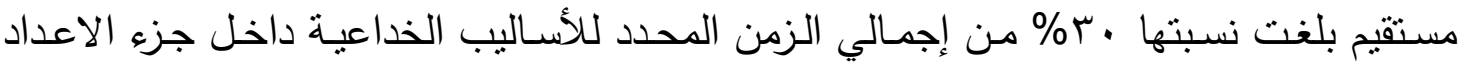

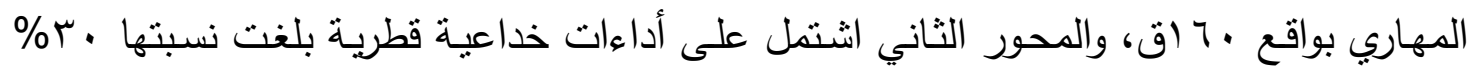

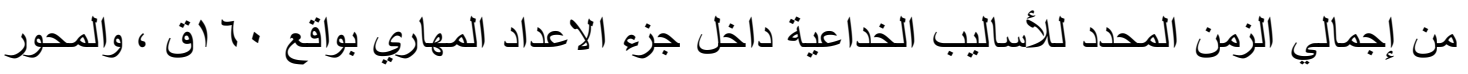

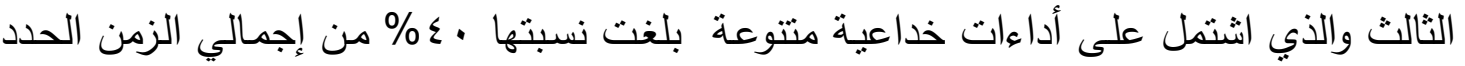
للأساليب الخداعية داخل جزء الاعداد المهاري بواقع با آبق، إضافة إلى تقنين الأحمال التدريبية

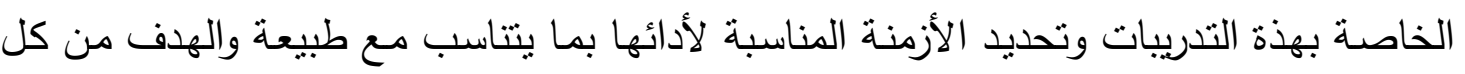
أسلوب.

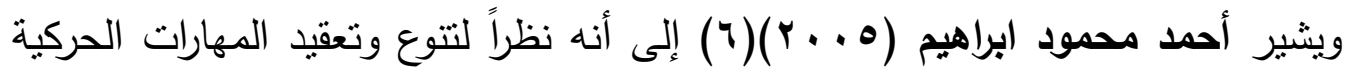

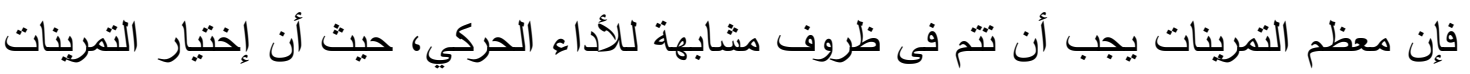

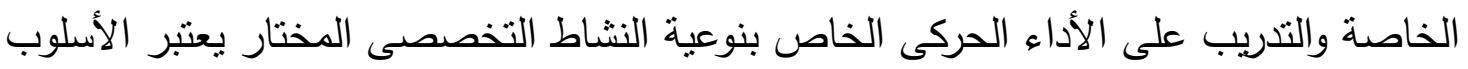

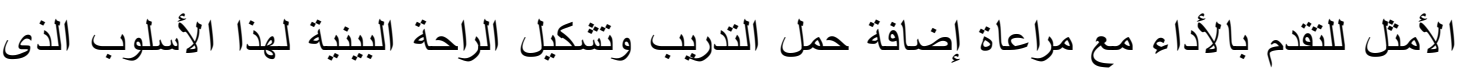
يؤدى إلى تتمية النواحى الوظيفية التى تدخل فى تتمية القدرات البدنية والمهارية الخاصة. كما يذكر "إبراهيم عبد الحميد الابياري" (V....rم)(1) أن التدريب الإرادي المنتظم والمستمر للاعب خلال البرامج التدريبية التي يتعرض لها على الجمل أو التكوينات المهارية

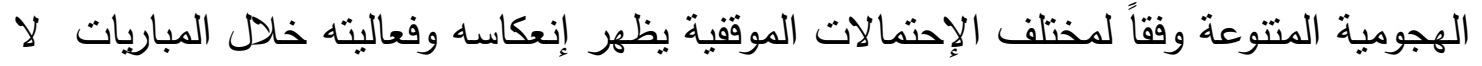


إرادياً في ردود أفعاله السريعة والصحيحة وأيضاً إمكانية أداء جمل أو تكوينات مهارية هجومية جديدة في ترتيجها داخل الخطة الهجومية الموقفية وفي طريقة أدائها وفقاً للموقف التتافسي الجديد.

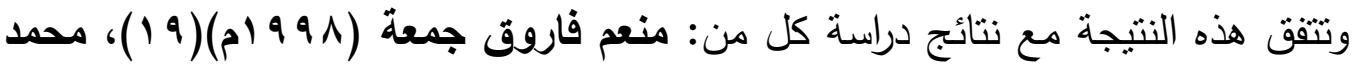

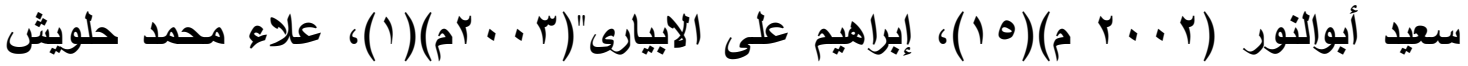

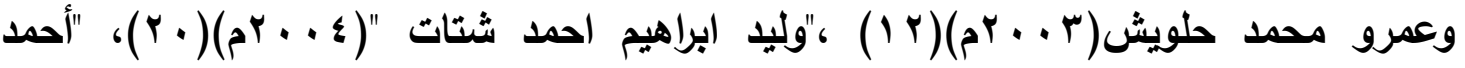

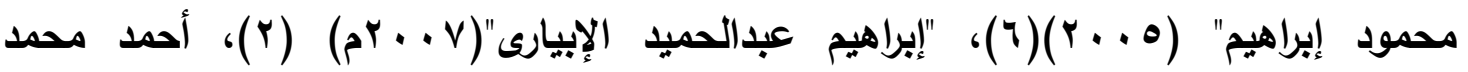

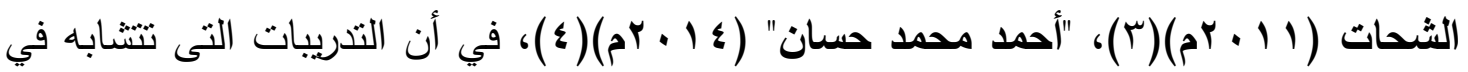

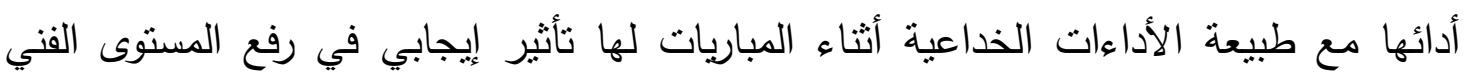
للحركات الخداعية والمهارية المصاحبة لها بشكل ملحوظ.

وبذلك يتحقق فرض البحث الأول والذي ينص على أنه : " توجد فروق دالة إحصائياً

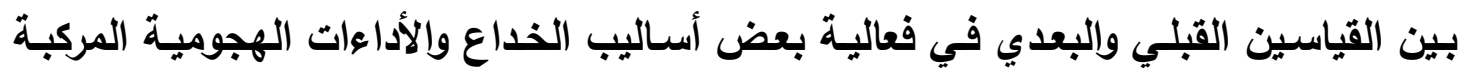
لاى المجموعة التجريبية ولصالح القياس البعدي. مناقشة نتائج الفرض الثاني:

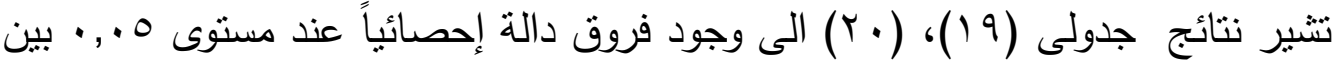

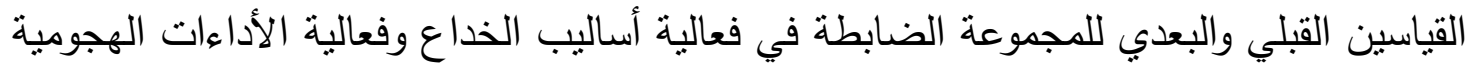

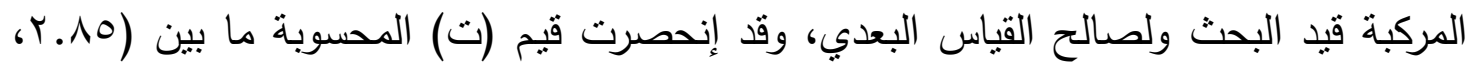

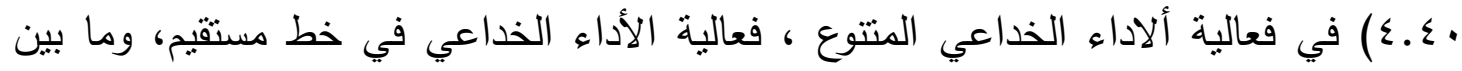
(O.Y. ، r.VA)

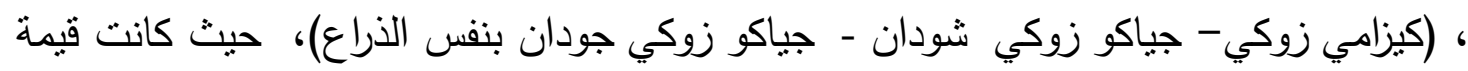

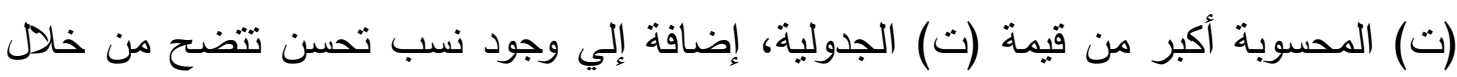

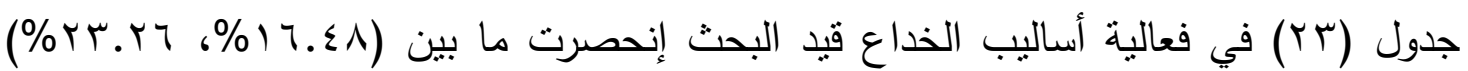

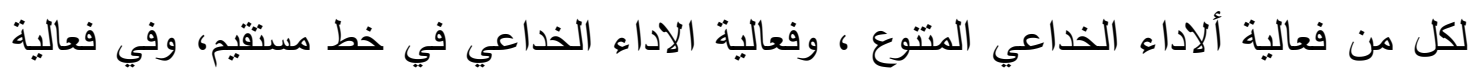

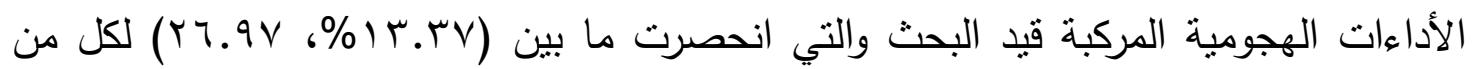
الأداء الهجومي المركب (كيزامي زوكي - جياكو زوكي)، الاداء الهجومي المركب (كيزامي لهي لهي زوكي- جياكو زوكي شودان - جياكو زوكي جودان بنفس الذراع). 
ويرجع الباحث هذه الفروق بين القياسين القبلي والبعدي للمجموعة الضابطة في فعالية

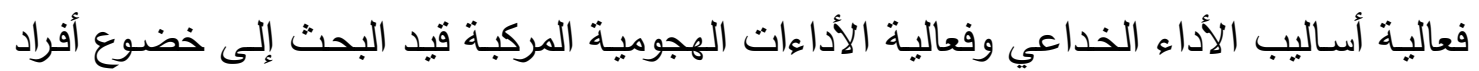

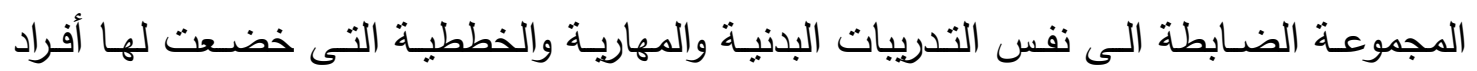
المجموعـة التجريبيـة باستنثاء الجزء الخـاص بتدريبات الأداءات الخداعيـة قيد البحث والتـي تم تطبيقها علي المجموعة التجريبية فقط داخل جزء الاعداد المهاري بالوحدة التدريبية اليومية . كما أن انتظام أفراد المجموعة الضابطة في التدريب كان له تأثثير ايجابي على مستوى

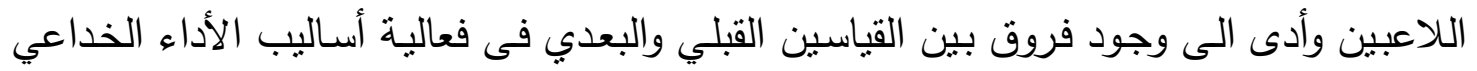
وفعالية الأداءات الهجومية.

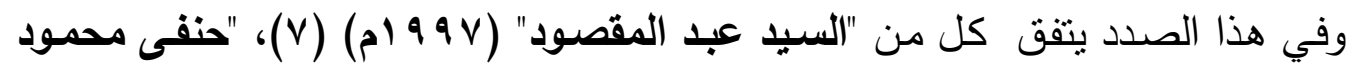

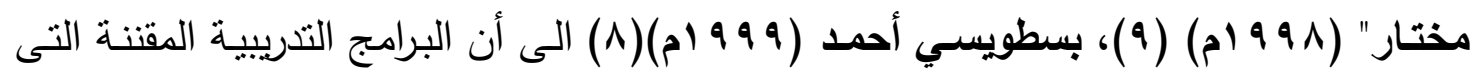

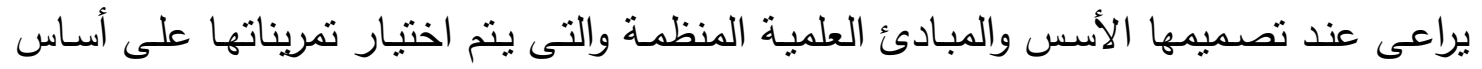

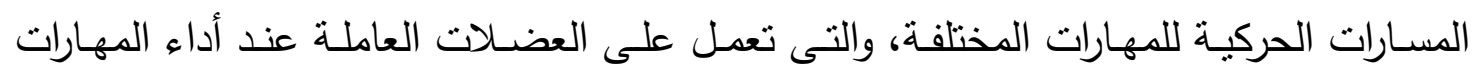
بصورة مباشرة تكون أكثر تركيزاً على نتمية الأداء البدنى والمهارى معاً. وتتفق هذه النتائج مع نتائج دراسة كل من منعم فاروق جمعة (9 9 ام)(9 (1))، محمد

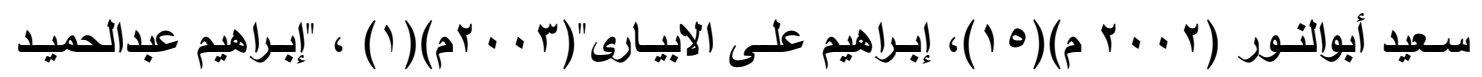

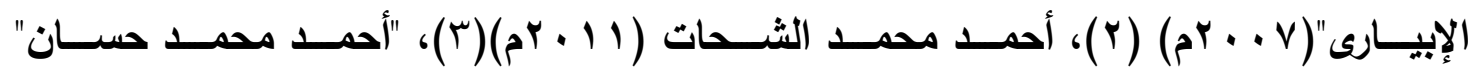

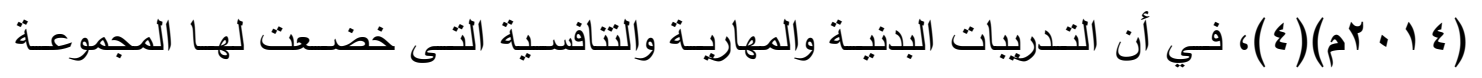
الضابطة كان لها تأثيراً إيجابي على فعالية الأداءات الهجومية أثثاء المباريات وذلك نتيجة لتكرار مجموعة الواجبات البدنية والمهارية والخططية على أفراد هذه المجموعة،. وبذلك يتحقق فرض البحث الثاني والذي ينص على أنه : " توجد فروق دالة إحصائياً

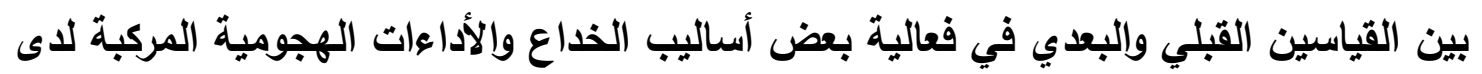
المجموعة الضابطة ولصالح القياس البعدي. مناقشة نتائج الفرض الثالث: تثير نتائج الجدولين (Yl)، (Yr) الى وجود فروق دالة إحصائياً عند مستوى 0 .,. بين القياسين البعديين للمجموعتين التجريبية والضابطة في فعالية أساليب الخداع وفعالية 
الأداءات الهجومية المركبة قيد البحث ولصالح المجموعة التجريية، وقد إنحصرت قيم (ت) المحسوبة ما بين (90.4، 0.0.0) في فعالية ألاداء الخداعي في خط مستقيم ، فعالية الأداء

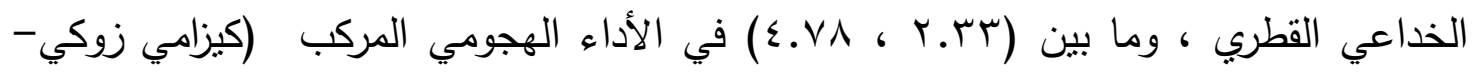
جياكو زوكي- كيزامي ماواشي) ، الاداء الهجومي المركب (كيزامي زوكي- كيزامي أورا ماواشي الأبي

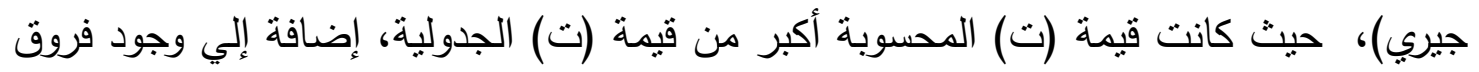

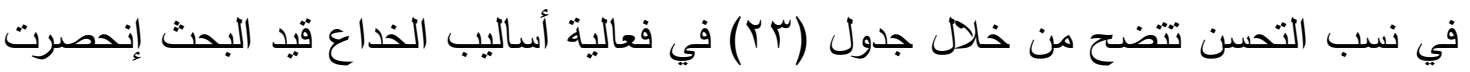

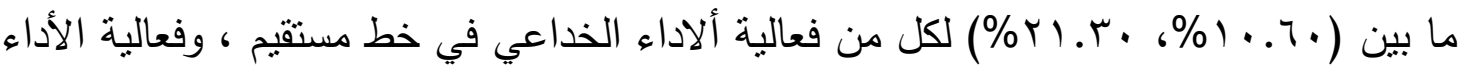

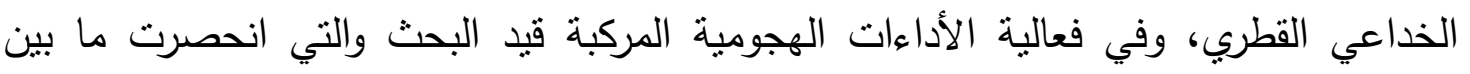

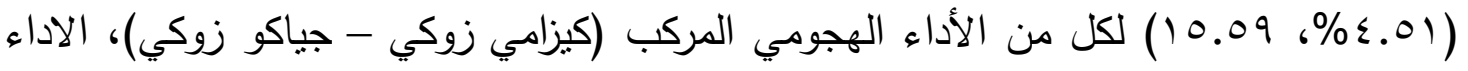

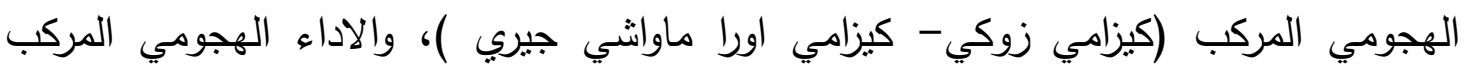
(كيزامي زوكي جياكو زوكي) ولصالح المجموعة التجريبية.

ويرجع الباحث هذه الفروق بين القياسين البعديين للمجموعتين التجريبية والضابطة في فعالية أساليب الخداع وفعالية الأداءات الهجومية المركبة قيد البحث، إلى التأثير الإيجابي البيدي

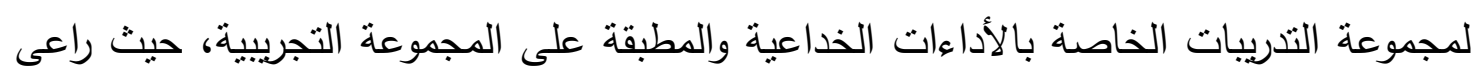
الباحث عند إختياره لهذه التدريبات أن تكون متتوعة ومرتبطة بطبيعة الأداءات الخداعية التي لخي تؤدى في مباريات الكوميتيه سواء كانت هذه الأداءات خداعية في خط مسنقيم أو أداءات خداعية

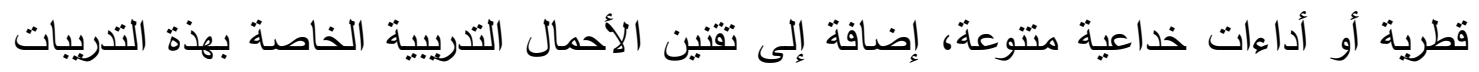

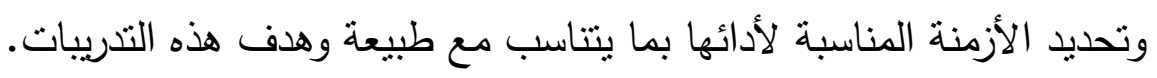

اضافة الى أن هذه التدريبات هي المتغير الذي تم إضـافته إلى المجموعة التجريبية دون

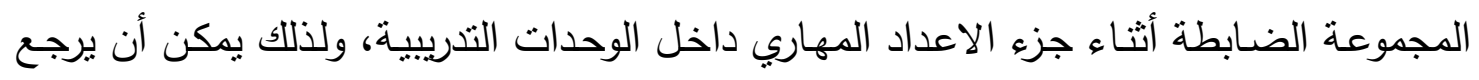

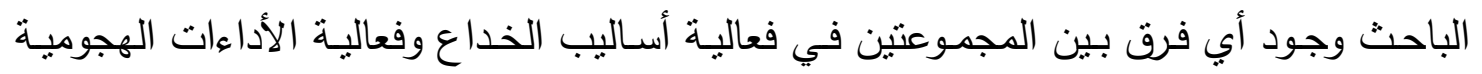
المركبة قيد البحث إلي هذا المتغير •

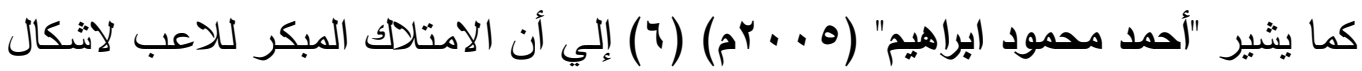

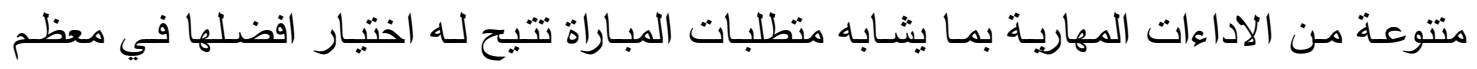

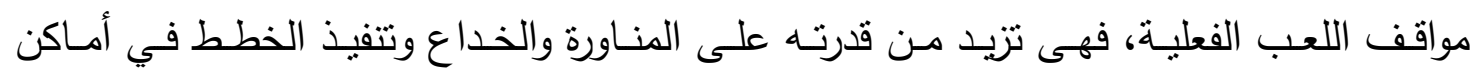
واتجاهات مختلفة، ولذلك لا يفاجأ بموقف لم يندرب عليه. 
وتتقق هذه النتيجة مع نتائج دراسة كل من منعم فاروق جمعة (991 ام)(9 (1)، محمد

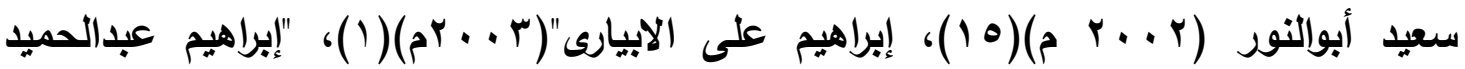

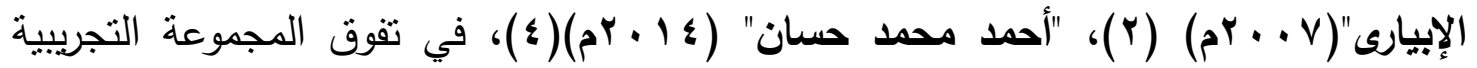
على المجموعة الضابطة في المستوى الفني للاداءات الخداعية والمهارات المصاحبة لها وزيادة فعالية الأداءات الهجومية بشكل ملحوظ.

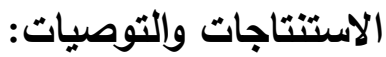

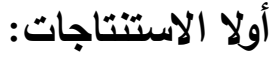

في ضوء هدف البحث وفروضده، وفي حدود عينة البحث، ومن واقع النتائج والبيانات

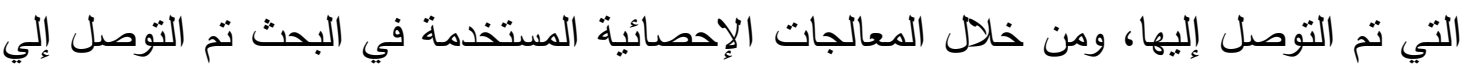

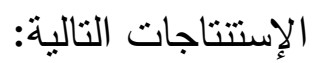

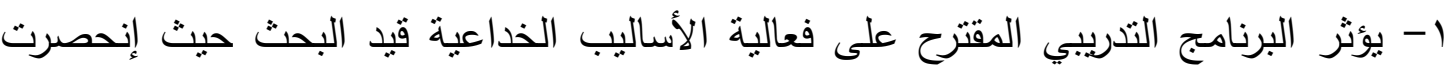

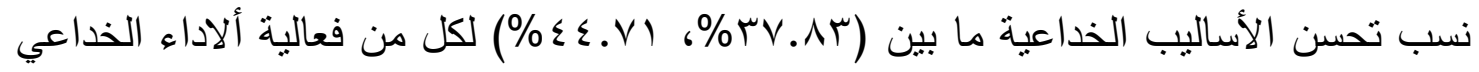

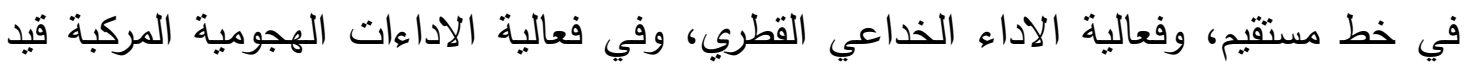

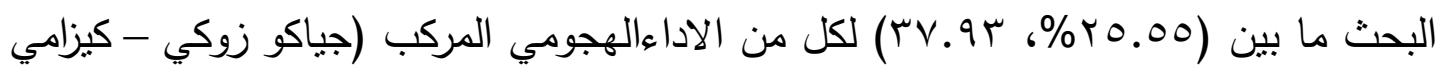
ماوانشي جيري)، الاداء الهجومي المركب (كيزامي زوكي- جياكو زوكي شودان - جياكو زوكي جودان بنفس الذراع). ץ- يؤدى إختبار تدريبات متتوعة ومشابهة للأداءات الخداعية المستخدمة في مباريات الكومينيه الى تحسن فعالية بعض أساليب الخداع والمهارات الهجومية المركبة لاتى ناثئي الكومينيه.

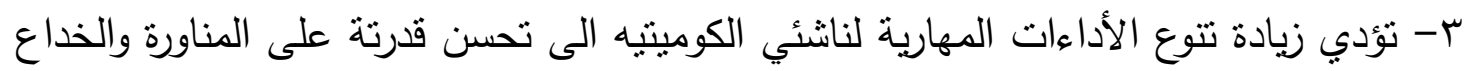
والقدرة على تنفيذ الواجبات المهارية والخططية المختلفة في أماكن واتجاهات متعددة من الملعب. ع - توجد فروق في نسب التحسن بين المجموعة التجريبية والمجموعة الضابطة في فعالية

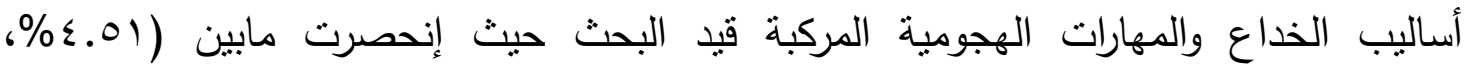

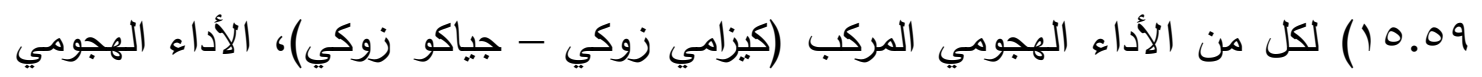

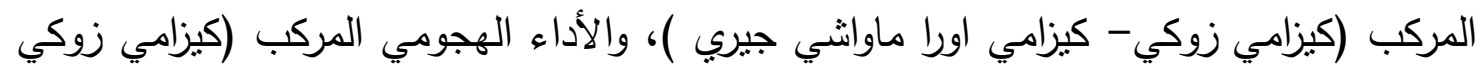
جياكو زوكي) ولصالح المجموعة التجريبية.

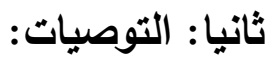
في ضوء ما توصل اليه الباحث من استتناجات يوصي بما يلي:

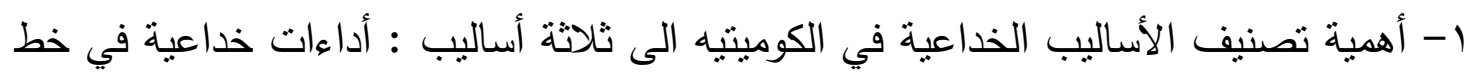
مستقير، أداءات خداعية قطرية، أداءات خداعية متتوعة. 
تأثير استخدام بعض أساليب الذاع على فعالية الأداءات الهجومية المركبة لناشئي الكوميتيه في رياضة الكارات

r- أهمية تقنين الأحمال التدريبية الخاصة بالاساليب الخداعية وتحديد الأزمنة المناسبة لأدائها بما يتتاسب مع طبيعة وهدف كل تدريب. r- أهمية تتفيذ التدربيات الخاصة بالأساليب الخداعية أثتاء الوحدات التذربيية داخل جزء المهاري.

ع - أهمية تدريب ناشُئي الكوميتيه على الاساليب الخداعية المختلفة في اماكن واتجاهات مختلفة من الملعب لما لها من أهمية في زيادة فعالية الأداء الهجومي اثناء المباريات. ه - أهمية تدربب اللاعب على أساليب خداعية ممانلة في نفس ظروف المنافسة حتى يتمكن من زيادة الحصيلة المهارية التى يعتمد عليها عند تعرضه لمواقف مختلفة أثناء المباريات.

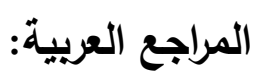

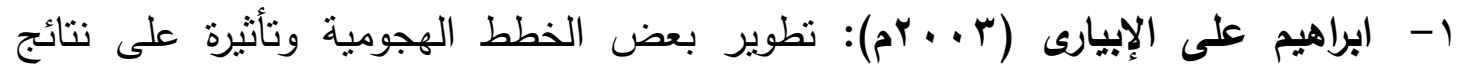
المباربات لدى ناشئي رياضة الكاراتيه، رسالة ماجستير ، كلية التربية الرباضية

بالسادات، جامعة المنوفية.

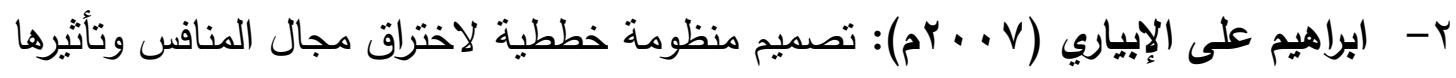
على فاعلية الأداء لدى لاعبي رياضة الكاراتيه،، رسالة دكتوراة ، كلية التربية

الرياضية بالسادات، جامعة المنوفية.

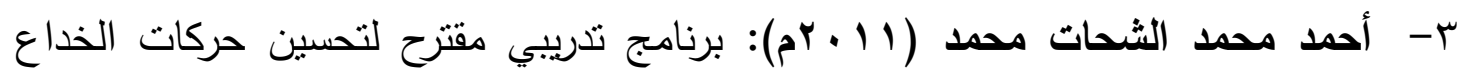
وتأثيرة علي معدل فاعلية أداءلاعبي التايكوندو، رسالة ماجستير، كلية التربية

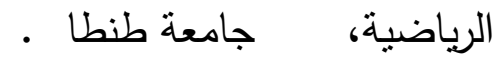

ع - أحمد محمد حسان(ع ا •rم): فاعلية تطوير بعض الموجات الهجومية القطرية على محددات الهجوم ونتائج المباريات لناشئي الكوميتيه في رياضة الكاراتيه، رسالة ماجستير ، كلية التربية الرياضية للبنين، جامعة بنها.

0- أحمد محمود محمد إبراهيم (99 (9 ام): مبادئ التخطيط للبرامج التعليمية والتدربيية رياضة الكاراتيه ، الطبعة الاولى، منشأة المعارف، الإهئ الاسكندرية.

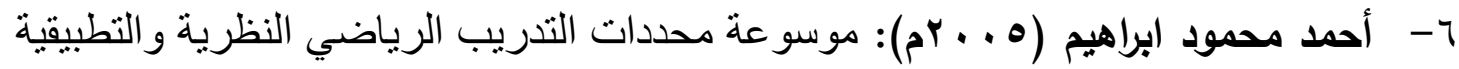
لتخطيط البر امج التدريبية برياضة (هود الكار اتيه، منشاة المعارف، الإسكندرية. -V - V مركز الكتاب للنشر ، القاهرة .

1 - بسطويسى أحمد بسطويسى(9 99 (م)): أسس ونظريات التدريب الرياضي ، دار الفكر العربي، القاهرة

9 - حنفى محمود مختار(9 9 (1م): أسس تخطيط برامج التدريب الرياضى"، دار زهران

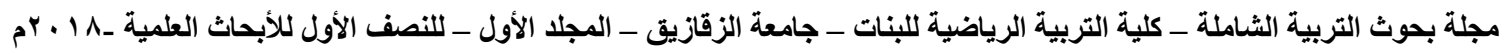


للنشر والتوزيع، القاهرة

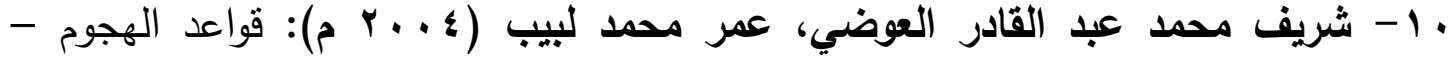
كوميتيه ، الطبعة الأولي، اسلاميك جرافيك، القاهرة. 1 - عبدالفتاح فتحي خضر (૧ 9 (ام): تحليل فاعلية التكنيك الهجومي لاى ملاكمي الدرجة

الاولى، بحث منشور، المؤتمر العلمي الاول، تاريخ الرياضة، جامعة المنيا.

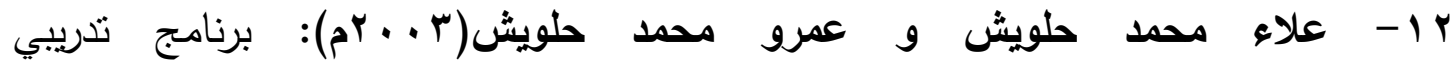
بإستخدام التدريبات النوعية لتحركات الرجلين أثناء أداء الموجات الهجومية أنوات كتدريب أولي) للاعبي الكاراتيه وتأثيرة علي تحقيق الإنجاز المبارائي، بحث منشور ،العددالأول، المجلة العلمية لعوم التربية الرياضية، كلية التربية الرياضية للبنات، جامعةا لإسكندرية.

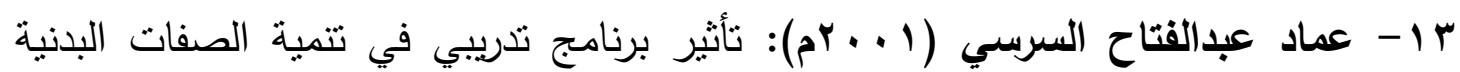

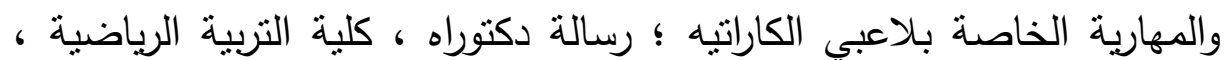

$$
\text { ط... }
$$

ـ ا - عويس الجبالي، تامر الجبالي († 1 • rم): منظومة التدريب الرياضي الحديث- النظرية والتطبيق، الطبعة الثالثة، مركز برنت، القاهرة.

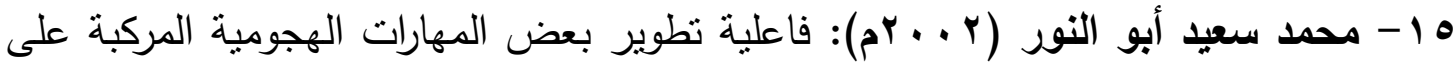
نتائج المباريات للاعبي الكوميتيه في رياضة الكاراتيه، رسالة ماجستير ، كلية التربية الرياضية للبنين، جامعة الزقازيق. 7 - 1 - محمد سعيد أبو النور (9 ( . rم): الإدراك الحس- حركي وعلاقته بفعالية الهجوم البسيط والمركب أثثاء مباريات الكوميتيه للاعبي الكاراتيه، المؤتمر العلمي الدولي الثالث، الجزء الثالث، كلية التربية الرياضية للبنين، جامعة الزقازيق، مصر ، من ع -

IV - محمود ريبع أمين البشيهى (O. . P م): تأثير برنامج تدريبي للخصائص المهارية والخططية وفق استراتيجية مباريات المستوي العالمي علي مستوي أداء ونتائج لاعبي رياضة الكاراتيه، رسالة دكتوراه، كلية التربية الرياضية للبنين بالقاهرة،

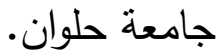

1 1 - معتز هلال أبو الأسعاد" ( • ( • r م): تأثير برنامج تدريبي على فاعلية أداء بعض المهارات الهجومية والدفاعية في مناطق اللعب المختلفة لناشئي الكومينيه في رياضة الكاراتيه، رسالة ماجستير ، كلية التربية الرياضية ، جامعة المنصورة. 
تأثير استخدام بعض أساليب الخاع على فعالية الأداءات الهجومية المركبة لناشئي الكوميتيه في رياضة الكارات

9 1 - منعم فاروق جمعة:(99191م): أثر تطوير بعض أنواع الخداع على مستوى الانجاز في الملاكمة، رسالة ماجستير ، كلية التربية الرياضية للبنين، جامعة الاسكندرية.

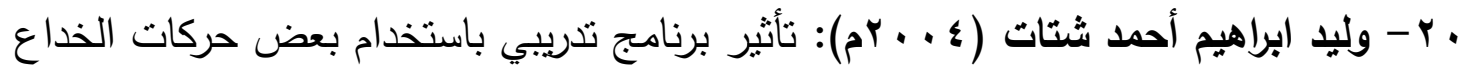
على مستوى الانجاز لاى لاعبي رياضة الجودو، رسالة ماجستير، كلية التربية الرياضية ، جامعة طنطا.

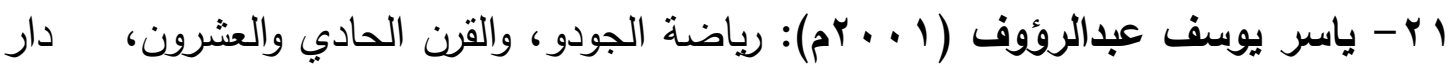

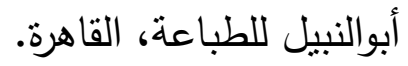

